NBER WORKING PAPER SERIES

\title{
FINANCIAL GLOBALIZATION, FINANCIAL CRISES, AND THE EXTERNAL PORTFOLIO STRUCTURE OF EMERGING MARKETS
}

\author{
Enrique G. Mendoza \\ Katherine A. Smith \\ Working Paper 19072 \\ http://www.nber.org/papers/w19072
NATIONAL BUREAU OF ECONOMIC RESEARCH
1050 Massachusetts Avenue \\ Cambridge, MA 02138
}

May 2013

We would like to thank two anonymous referees and the guest editor at the Scandinavian Journal of Economics, Gita Gopinath, for their helpful comments and suggestions. We also thank Gian Maria Milesi-Ferretti and Philip Lane for their dataset on foreign asset positions. The views expressed herein are those of the authors and do not necessarily reflect the views of the National Bureau of Economic Research.

NBER working papers are circulated for discussion and comment purposes. They have not been peerreviewed or been subject to the review by the NBER Board of Directors that accompanies official NBER publications.

(C) 2013 by Enrique G. Mendoza and Katherine A. Smith. All rights reserved. Short sections of text, not to exceed two paragraphs, may be quoted without explicit permission provided that full credit, including $\odot$ notice, is given to the source. 
Financial Globalization, Financial Crises, and the External Portfolio Structure of Emerging Markets

Enrique G. Mendoza and Katherine A. Smith

NBER Working Paper No. 19072

May 2013

JEL No. D52,E44,F32,F41

\begin{abstract}
We study the short- and long-run effects of financial integration in emerging economies using a two-sector model with a collateral constraint on external debt and trading costs incurred by foreign investors. The probability of a financial crisis displays overshooting: It rises sharply initially and then falls sharply but remains positive in the long run. While equity holdings fall permanently, bond holdings initially fall but rise after the crisis probability peaks. Conversely, asset returns and asset prices first rise and then fall. These results are in line with the post-globalization dynamics observed in emerging markets, and the higher frequency of crises they displayed. Without financial frictions, the model yields a negligible fall in equity and a large increase in debt. The results also depend critically on supply-side effects of financial frictions affecting the price of nontradables and dividends from nontradables producers, and on strong precautionary savings incentives induced by the risk of financial crises.
\end{abstract}

\author{
Enrique G. Mendoza \\ Department of Economics \\ University of Pennsylvania \\ 3718 Locust Walk \\ Philadelphia, PA 19104 \\ and NBER \\ egme@sas.upenn.edu \\ Katherine A. Smith \\ United States Naval Academy \\ Department of Economics \\ 589 McNair Road \\ Mail Stop 10-D \\ Annapolis, MD 21402 \\ ksmith@usna.edu
}




\section{Introduction}

Financial globalization affected the portfolio structure of net foreign assets (NFA) in emerging markets in a strikingly different manner than in industrial countries ${ }^{1}$ As seen in Figure 1, by 2007, roughly twenty years after the trend for financial globalization started, the average emerging economy (weighted by GDP) held a large negative net equity position of nearly -28 percent of GDP, and a positive net position in debt instruments almost as large in absolute value. In contrast, the average industrial country was sharply short in debt instruments (-20 percent of GDP) and long in equity (almost 12 percent GDP). These clear differences in the NFA portfolio followed from a transition process during which net debt rose sharply and net equity fell sharply in emerging markets, and the opposite occurred in industrial economies.

It is well-known that the accumulation of reserves by many emerging economies has been a driving force of the surge in their holdings of debt instruments. Figure 2 shows, however, that the large and persistent portfolio re-balance that took place in emerging markets also had a lot to do with adjustments in external liabilities. Since the mid 1990s, emerging markets took on much greater equity liabilities (i.e. purchases of domestic equity by foreign agents) and reduced their debt liabilities, in addition to increasing debt assets by accumulating foreign reserves.$^{2}$ The fall in debt liabilities is also reflected in the narrowing gap between the total net debt position and holdings of reserves in Figure 1. Moreover, it is also evident that changes in equity assets played a minor role, because they remain a very small fraction of total external wealth.

In the early stages of the transition to financial globalization, it seemed unlikely that there would be such large long-run changes in external positions. The Chinn and Ito (2007) financial openness measure shows that, while financial integration across industrial countries started in the late 1970s, the major shift towards world-wide financial integration, including emerging markets, started around 1987 (See Appendix Figure A.1). From then and through the mid 1990s, changes

\footnotetext{
${ }^{1}$ We use the terms financial integration and financial globalization interchangeably and define them as the selling/buying of financial assets across countries. We use the Lane and Milesi-Ferretti (2006) database to document the stylized facts of external assets. We define equity assets and liabilities as the sums of positions in portfolio equity and FDI, and debt assets as the sum of portfolio debt assets, other investment, and total reserves minus gold

${ }^{2}$ The surge in debt assets is fully driven by the surge in reserves. Excluding them, debt assets remained fairly stable around 20 percent of the total of gross external assets and liabilities.
} 
Figure 1: External Capital Structures (GDP weighted)

(a) Emerging Markets

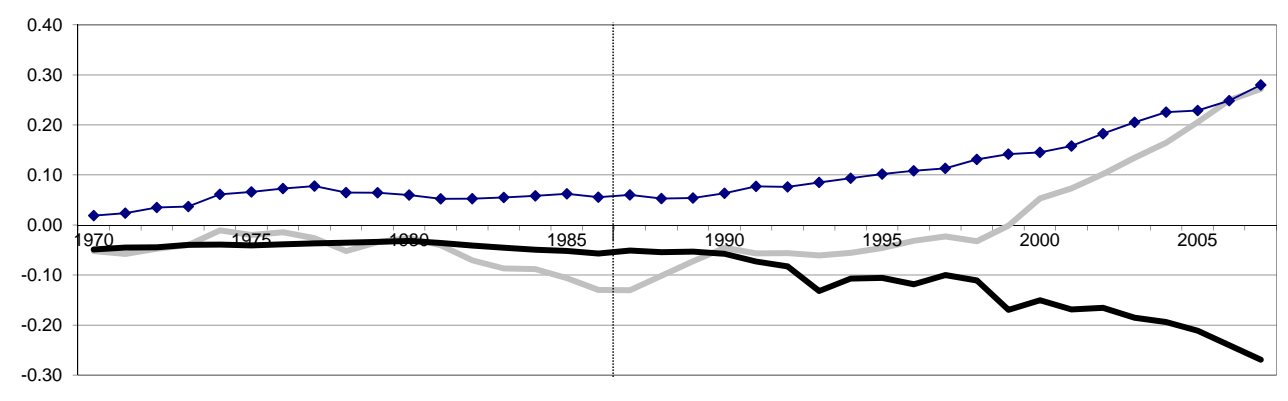

(b) Industrial Countries

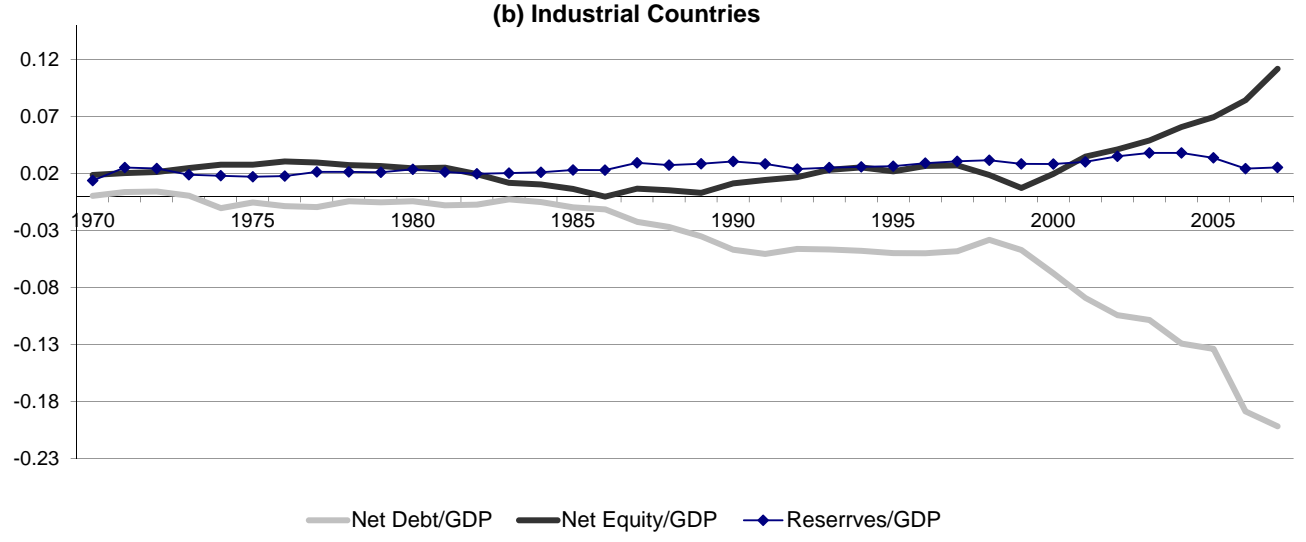

Note: Original source Lane and Milesi-Ferretti (2006). Updated through 2007. GDP weights are time varying. Net calculations refer to assets minus liabilities. Debt assets include portfolio debt, other debt, and reserves minus gold. Debt liabilities refer to portfolio debt and other debt. Equity assets and liabilities include portfolio equity and foreign direct investment. See Appendix for a list of included countries. 
in net debt and equity positions in both emerging markets and industrial countries were relatively small, and thus the gap between net debt and net equity positions in each country group was fairly stable (see Figure 1).

The initially slow-paced movements in external assets contrast sharply with the changes that took place in the aftermath of the emerging markets crises of the 1990s, starting with the Mexican crisis of 1994-95. These so called Sudden Stop crises were characterized by sharp reversals in capital inflows, deep recessions, and steep collapses in real asset prices. ${ }^{3}$ After the Sudden Stops, net equity started to fall at a rapid pace and net debt started to rise in emerging markets, and industrial countries displayed opposite trends, producing the striking differences in net external positions that we observe today. ${ }^{4}$ Gross positions in emerging markets displayed similar trends. In particular, in the decade after 1997, equity liabilities surged and debt liabilities fell, driving almost all of the fall in net equity and more than half of the rise in net debt respectively.

This paper shows that the marked shift in the external asset positions of emerging markets post-financial integration following the Sudden Stops is an equilibrium outcome of the transitional dynamics of financial integration with imperfect capital markets, and that these dynamics also feature substantial overshooting in the likelihood of experiencing Sudden Stops during the transition. We conduct a quantitative study of the transitional dynamics of financial integration in an equilibrium business cycle model with aggregate, non-insurable risk, in which a small open economy is vulnerable to financial crises because of two frictions in world capital markets: A Fisherian collateral constraint that restricts foreign borrowing not to exceed a fraction of the market value of domestic equity holdings, and asset trading costs incurred by foreign agents in trading equity with the small open economy. Moreover, the model includes tradable and nontradable goods, and this

\footnotetext{
${ }^{3}$ There is some heterogeneity across countries in terms of which macro aggregates were affected most. For instance, in the 1994 Mexican crisis, real equity prices fell by 29 percent, the current account rose by 5.2 percentage points of GDP, industrial output fell nearly 10 percent and consumption declined by 6.5 percent. Argentina's 1995 crisis resulted in collapses in real equity prices and industrial output similar to Mexico's, a current account reversal of 4 percentage points of GDP, and a decline in consumption of 4 percent. In contrast, the Korean and Russian crises stood out for their large current account reversals of 11 and 9.5 percentage points of GDP respectively, and for the widespread contagion across world financial markets. Also, Sudden Stops can occur even without a currency crisis, as was the case in Hong Kong (1997) and Argentina (1995).

${ }^{4}$ There is some degree of heterogeneity within countries in each group. In industrial countries, for example, Spain has a large negative net debt position while Germany does not. In the emerging economies, Turkey has a large negative net debt position.
} 
Figure 2: Decomposition of the External Capital Structure (GDP weighted): Emerging Markets

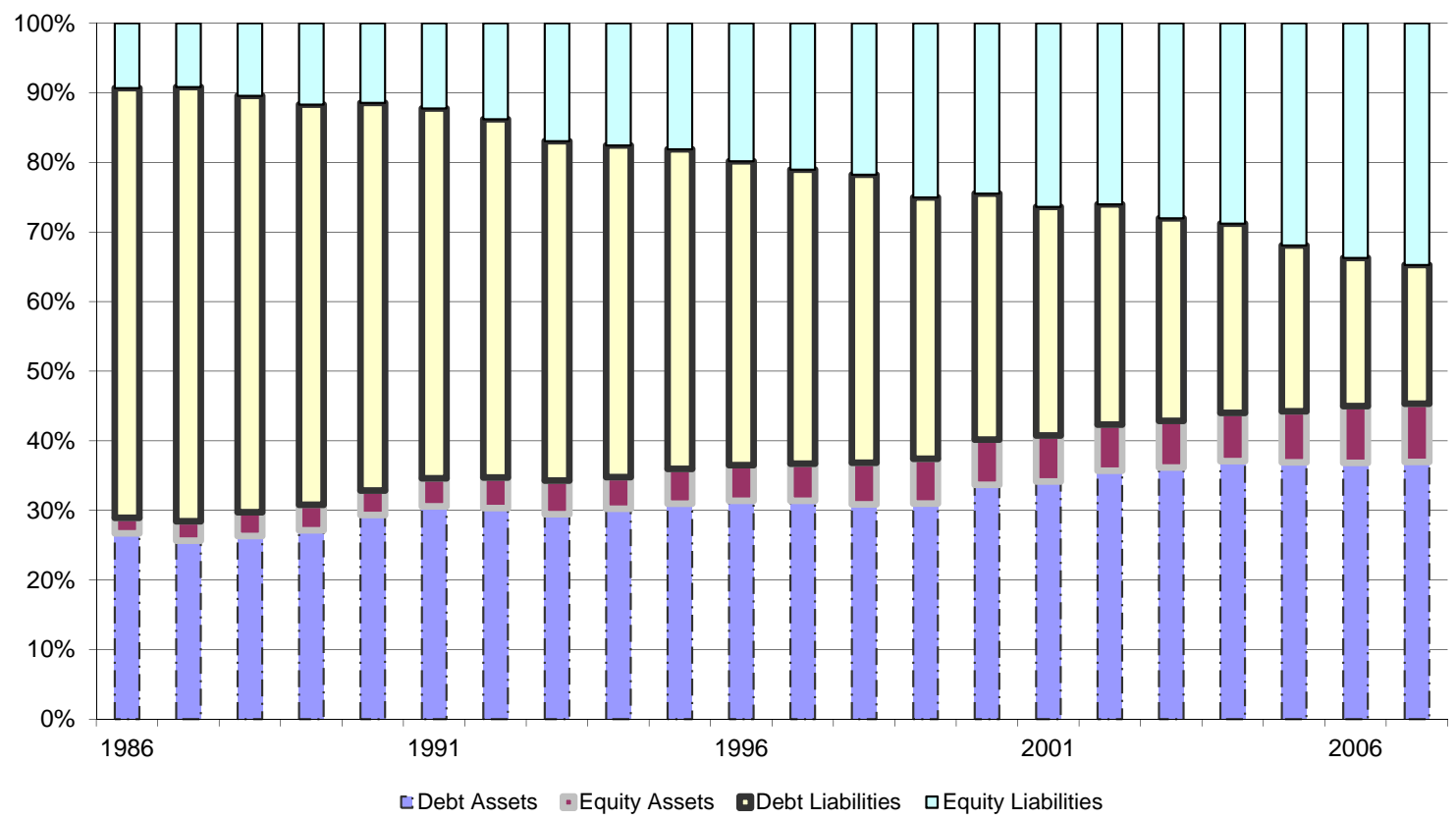

Note: Original source Lane and Milesi-Ferretti (2006). Updated through 2007. GDP weights are time varying. Net calculations refer to assets minus liabilities. Debt assets include portfolio debt, other debt, and reserves minus gold. Debt liabilities refer to portfolio debt and other debt. Equity assets and liabilities include portfolio equity and foreign direct investment. See Appendix for a list of included countries. 
allows financial crises to induce important effects on production, dividends and the real exchange rate, which in turn strengthen the Fisherian financial amplification mechanism.

The collateral constraint and the portfolio adjustment costs are crucial for the link between financial integration, the probability of crisis and the long-run external capital structure that drives the model's results $5^{5}$ The transitional dynamics of financial integration without these frictions yields a very small decline in equity holdings and a large increase in debt.

The transitional dynamics at work in the model operate as follows: Upon opening the financial account of the emerging economy, a fall in the real interest rate and the desire to smooth consumption induce agents to borrow from abroad and increase leverage. Equity returns fall because of the lower risk-free rate and the lower risk premium implied by the improved consumption smoothing (i.e. a lower covariance between consumption and equity returns). Quantitatively, these effects pushing down on asset returns dominate relatively weaker offsetting effects, which are induced by the incentive agents have to share risk by reducing holdings of assets that co-vary with their own income (i.e. domestic equity), and by the expectation of sharp increases in expected returns in future states in which financial crises could occur. As a result, equity prices rise on impact when the transitional dynamics of financial integration start, and domestic agents refrain from reducing their equity holdings for a few periods.

Given the initial rise in equity prices and the slow debt buildup from zero initial bond holdings, financial integration starts with the economy far from being credit constrained and encouraged to increase debt and leverage. But rising leverage increases the probability of hitting the credit constraint, and as this happens risk premia start to rise, exerting downward pressure on equity prices, which in turn increase leverage further (as debt increases and asset values fall) feeding back into higher crises probabilities. Higher risk premia and the risk-sharing incentives for reducing equity holdings eventually strengthen to the point that agents start re-balancing their portfolio by selling equity. Because buying equity is costly for foreign traders, however, the pressure for equity prices to fall increases. In turn, with a lower value of equity, the leverage of domestic agents rises

\footnotetext{
${ }^{5}$ While financial frictions are present in both Emerging and Industrialized economies, our assumption is that they are less severe for the former, because those frictions result from institutional features of credit contracts (e.g. limited enforcement) and/or informational frictions that are also likely to be less severe.
} 
even more, leaving them exposed to a greater risk of hitting the credit constraint. If this does happen, the classic Fisherian debt-deflation mechanism is set in motion and a full-blown financial crisis follows. The crisis is characterized by a fire-sale of equity and a sudden reversal in the debt position and the current account.

The risk of financial crises has permanent impacts on the economy's external capital structure, as agents adjust their portfolios to reduce the probability of crises in the long-run by lowering equity holdings and increasing their holdings of bonds. As a result, the leverage ratio is significantly lower than in an economy where credit frictions are not present and therefore a debt deflation crisis is not a threat. In addition, the magnitude of the trading costs greatly affects the equity price dynamics and in turn affects the long-term capital structure.

The strengthened financial amplification mechanism that results from the introduction of nontradable goods is also important for the model's performance. A financial crisis causes deflation in nontradables prices (i.e. a collapse of the real exchange rate) as the consumption of tradables drops more than nontradables (due to relative supply elasticities), and this introduces two adverse effects on equity prices. First, since future dividends from nontradables are valued in units of tradables, the risk of real exchange rate collapse affects equity prices. Second, since nontradable firms make optimal production plans by choosing demand for variable inputs, a deflation of nontradables prices lowers the value of the marginal product of these inputs, thus reducing demand for inputs and the production and dividends from nontradables producers. The feedback loop operating in the Fisherian debt-deflation mechanism is strengthened then, because lower asset prices force larger corrections in tradables consumption, and thus larger deflation in nontradables, which then feeds back into even larger asset price drops ${ }^{6}$

If financial integration produces overshooting in the likelihood of financial crises and leads to substantially lower equity holdings and higher bond holdings in the long run, a natural followup question arises: Would these effects vary under different strategies for financial opening? In particular, we explore how strategies that open only debt, only equity, or both debt and equity

\footnotetext{
${ }^{6}$ Following Mendoza (2010), we infer that adding an investment decision would likely amplify the impact of the equity price feedback, because the collapse of investment would shrink collateral more than with an asset in fixed supply. On the other hand, the reduction in the supply of assets can result in a smaller asset price decline.
} 
markets differ. For instance, if a country only opens to equity flows but allows no debt, a debtdeflation crisis cannot occur because the external credit constraints are irrelevant. The downside, however, is that the economy cannot smooth consumption as well.

The contribution of this paper is in that it focuses on the link between Sudden Stops, capital account liberalization, and the dynamics of both the NFA position and the portfolio of external assets. This is in contrast with the emphasis in a large fraction of the open-economy macro literature on financial liberalization, which studies the effects of financial liberalization on growth (e.g. Kraay (1998)) and currency crisis (e.g. Kaminsky and Reinhart (1999) Demirguc-Kunt and Detragiarche (1998) and Glick and Hutchinson (2001)).

This paper is related to the literature aiming to explain the surge in foreign reserves in emerging economies. A common notion in this literature is that countries choose to build up assets to selfinsure against the risk of future crises. The studies by Aizenman and Lee (2007), Alfaro and Kanczuk (2006), Caballero and Panageas (2006), Choi et al. (2007), Durdu et al. (2008), Jeanne and Ranciere (2006), and Jeanne (2007) examine key theoretical and empirical features of this idea. As we noted, however, Sudden Stops were followed by a large rise in equity liabilities and a fall in debt liabilities, in addition to the increase in reserves (see Figure 2). While in 1986 equity liabilities contributed roughly $9 \%$ to the emerging markets external position, by 2007 the contribution rose to $35 \%$. Likewise, in 1986 debt liabilities were roughly $70 \%$, and by 2007 they fell to about $20 \%$. Thus, understanding the full impact of the effects of globalization and Sudden Stops on external assets of emerging economies requires modeling both debt and equity instruments. Moreover, the emphasis on the equity side should be on explaining the surge in equity liabilities, because equity assets are negligible. In line with these observations, the model proposed in this paper provides solutions for total NFA and bonds and equity positions, and on the equity side it focuses on equity liabilities, abstracting from domestic purchases of foreign equity.

While there is consensus in the Sudden Stops literature in that financial frictions were an important propagation mechanism, there are different approaches to model them. In much of the literature, the current account reversal itself is modeled as a large exogenous shock either directly to external borrowing or indirectly to the world interest rate, rather than as an endogenous outcome 
of financial frictions (see for example Calvo (1998) and Christiano et al. (2000)). Other studies, as Mendoza (2010) and Mendoza and Smith (2006), use global numerical methods to examine the quantitative predictions of non-linear models in which financial crises are an endogenous outcome produced by financial amplification in response to productivity shocks identical to those that drive frictionless real-business-cycle models. The model we propose here is in this vein.

The model extends the setup in Mendoza and Smith (2006) in three important ways. First, as explained above, we build a two-sector structure with tradable and nontradable goods, which amplifies the debt deflation dynamics and raises the probability of a debt-deflation crisis. Second, while in Mendoza and Smith (2006) production and dividends are unaffected by financial crises, in the model of this paper production of nontradables and the stream of dividends are affected by the debt-deflation dynamics, which strengthens the financial amplification mechanism. Third, Mendoza and Smith (2006) focused on comparing crisis and business cycle dynamics with and without credit frictions under perfect capital mobility, and this paper focuses instead on studying the transitional dynamics of financial integration, particularly the dynamics of bond and equity holdings and the probability of crisis in the long run and the short run.

This analysis is also in a similar line as the literature on global imbalances. The theoretical branch of this literature focuses largely on total current account imbalances or NFA positions, with only some studies highlighting differences in portfolio structures. In particular, Mendoza et al. (2009) shows that financial integration results in the country with the less developed financial markets building a large positive NFA position composed of large positive debt and negative equity holdings. The model examined in this paper is of more limited scope, in the sense that it focuses only on a small open economy, and hence it cannot provide a full explanation of global imbalances. On the other hand, it develops and explanation for the portfolio structure of emerging economies based on increased risk to a financial crisis under financial integration in a setup with aggregate uncertainty and non-linear debt-deflation dynamics.

The rest of the paper is organized as follows. Section 2 describes the model. Section 3 represents the model's equilibrium in recursive form and describes the solution method. Section 4 discusses the quantitative results. Section 5 compares different strategies to open the capital account. Finally, 
Section 6 summarizes our main findings.

\section{A Model of Financial Integration with Financial Frictions}

The model is a general equilibrium asset-pricing framework with financial frictions and aggregate risk similar to Mendoza and Smith (2006) but extended to include tradables and non-tradables, imported inputs, external assets denominated in units of tradables (i.e. "liability dollarization"), and dividends and production that are affected by financial frictions. Domestic agents are modeled as a risk-averse, representative-agent small open economy subject to non-diversifiable productivity shocks. With full financial integration, this economy trades bonds and equity with the rest of the world. The economy's ability to borrow is limited by a collateral constraint, and to make this constraint nontrivial, there is also a short-selling constraint that imposes a lower bound on domestic equity holdings. Foreign agents are made of two entities: a set of foreign securities firms specialized in trading equity of the small open economy, and the usual global credit market of non-statecontingent, one-period bonds that sets the world's real interest rate via the standard small-openeconomy assumption. Foreign traders face recurrent and per-trade costs in trading equity with the small open economy.

\subsection{Domestic Firms}

The tradables output is in the form of an endowment $y^{T}$. The price of tradable goods is the numeraire, and it is assumed to be set in world markets and equal to 1 for simplicity.

The nontradables sector consists of a large number of identical firms that use labor $\left(L_{t}\right)$ and imported intermediate goods $\left(m_{t}\right)$ as variable factors of production, along with a fixed amount of capital $(K)$. Firms produce this good using a Cobb-Douglas technology $\exp \left(\varepsilon_{t}\right) L_{t}^{\psi} m_{t}^{\zeta} K^{1-\psi-\zeta}$ where $\exp \left(\varepsilon_{t}\right)$ is a Markov productivity shock. Nontradables output is priced at $p_{t}^{n}$, which is the relative price of nontradables to tradables and determines the real exchange rate. Firms choose labor $L_{t}$ and imported intermediate goods $m_{t}$ in order to maximize profits taking wages, $w_{t}$, intermediate goods prices, $p_{t}^{m *}$, and the price of nontradables as given. Profits are defined as follows: 


$$
p_{t}^{n} \exp \left(\varepsilon_{t}\right) L_{t}^{\psi} m_{t}^{\zeta} K^{1-\psi-\zeta}-w_{t} L_{t}-p_{t}^{m *} m_{t}
$$

The assumption that the stock of capital is an exogenous constant is adopted for simplicity.

Factor demands for $t=0, \ldots, \infty$ are given by standard marginal productivity conditions:

$$
\psi p_{t}^{n} \exp \left(\varepsilon_{t}\right) L_{t}^{\psi-1} m_{t}^{\zeta} K^{1-\psi-\zeta}=w_{t}
$$

$$
\zeta p_{t}^{n} \exp \left(\varepsilon_{t}\right) L_{t}^{\psi} m_{t}^{\zeta-1} K^{1-\psi-\zeta}=p_{t}^{m *}
$$

Dividend payments for $t=0, \ldots, \infty$ are thus given by:

$$
d_{t}=(1-\psi-\zeta) p_{t}^{n} \exp \left(\varepsilon_{t}\right) L_{t}^{\psi} m_{t}^{\zeta} K^{-\psi-\zeta}
$$

Productivity shocks follow a two-point, symmetric Markov chain. The shocks take a high or low value $\varepsilon_{H}, \varepsilon_{L}$. Symmetry implies that $\varepsilon_{L}=-\varepsilon_{H}$. The long run probabilities of each state satisfy $\Pi\left(\varepsilon_{L}\right)=\Pi\left(\varepsilon_{H}\right)=1 / 2$. Transition probabilities follow the simple persistence rule (Backus et al. (1989)): $\pi_{\varepsilon_{i} \varepsilon_{j}}=(1-\vartheta) \Pi\left(\varepsilon_{j}\right)+\vartheta I_{\varepsilon_{i} \varepsilon_{j}} I_{\varepsilon_{i} \varepsilon_{j}}=1$ if $i=j$ and 0 otherwise, for $i, j=L, H$. This specification minimizes the size of the exogenous state space $\mathrm{E}$ without restricting the variance and first-order autocorrelation of the shocks. Under these assumptions, the shocks have zero mean, their variance is $\left(\varepsilon_{H}\right)^{2}$, and their autocorrelation coefficient is given by $\vartheta$.

\subsubsection{Households}

A large number of identical, infinitely-lived households inhabit the small open economy. Their preferences are represented by the Stationary Cardinal Utility (SCU) function proposed by Epstein (1983), which features an endogenous rate of time preference:

$$
U=E\left[\sum_{t=0}^{\infty} \exp \left(-\sum_{\tau=0}^{t-1} \nu\left(c_{\tau}\right)\right) u\left(c_{t}\right)\right]
$$

where $c_{t}$ represents a CES composite good of tradable and nontradable goods: 


$$
c\left(c_{t}^{T}, c_{t}^{N}\right)=\left[z\left(c_{t}^{T}\right)^{-\mu}+(1-z)\left(c_{t}^{N}\right)^{-\mu}\right]^{-1 / \mu}, \quad z>0, \quad \mu \geq-1
$$

The elasticity of substitution between tradables and nontradables is given by $1 /(1+\mu)$, and the CES weighting factor is given by $z$. The period utility function $u$ is a standard continuously differentiable, concave utility function. The time preference function $\nu$ must satisfy $\nu(*)>0$, $\nu^{\prime}(*)>0, \nu^{\prime \prime}(*)<0$, and $u^{\prime}(*) \exp (\nu(*))$ non-increasing.

Preferences with endogenous impatience are useful in stochastic small open economy models with incomplete insurance markets because foreign asset holdings diverge to infinity with the standard assumption of an exogenous rate of time preference equal to the world's interest rate. Preferences with a constant rate of impatience support a well-defined stochastic steady state only if the rate of interest is set lower than the rate of time preference arbitrarily, but in this case the mean foreign asset position is largely determined by the ad-hoc difference between the two rates (see Arellano and Mendoza (2003) for details). In models with credit constraints, endogenous impatience is also useful for supporting stationary equilibria in which these constraints bind.

Households maximize SCU subject to the following period budget constraint:

$$
c_{t}^{T}+p_{t}^{N} c_{t}^{N}=y_{t}^{T}+\alpha_{t} K d_{t}+w_{t} L_{t}+q_{t}\left(\alpha_{t}-\alpha_{t+1}\right) K-b_{t+1}+b_{t} R
$$

where $\alpha_{t}$ and $\alpha_{t+1}$ are beginning- and end-of-period shares of the domestic capital stock owned by domestic households, $b_{t}$ and $b_{t+1}$ are holdings of one-period international bonds denominated in units of tradables, $q_{t}$ is the price of equity, and $R$ is the gross real interest rate faced by the small open economy in world credit markets. The supply of labor is assumed to be inelastic and set to 1 for simplicity. Hence, labor in the model is used only so that endogenous variability in labor demand in response to shocks and relative price movements induces non-insurable variability in wages, and thus in household income.

At equilibrium, the relative price of nontradables affects the households budget constraint directly and indirectly. Directly, because $p_{t}^{N}$ affects the value of the expenditure on non-tradables consumption in the standard way. Indirectly, because the price of nontradables affects producers 
plans, and thus dividends and wages.

In addition to the budget constraint, households face a collateral constraint or margin requirement, according to which they cannot borrow more than a fraction $\kappa$ of the value of assets offered as collateral:

$$
b_{t+1} \geq-\kappa q_{t} \alpha_{t+1} K
$$

Households also face a short-selling constraint $\alpha_{t} \geq \chi$ for $-\infty<\chi<1$ and $t=1, \ldots, \infty$. The case in which $\chi$ is positive can be interpreted as a portfolio requirement, or as a constraint stating that only a fraction of the capital stock of the emerging economy is tradable in international equity markets. The constraint $\alpha_{t} \geq \chi$ is needed to ensure that the state space of portfolio holdings is compact and that the collateral constraint is not irrelevant. With unlimited short selling of equity, domestic agents could always undo the effect of the credit constraint (see Mendoza and Smith (2006) for further details).

The first-order conditions of the household's problem are

$$
\begin{gathered}
U_{c_{t}^{T}}(\cdot)=\lambda_{t} \\
U_{c_{t}^{N}}(\cdot)=p_{t}^{N} \lambda_{t} \\
q_{t}\left(\lambda_{t}-\eta_{t} \kappa\right)=E_{t}\left[\lambda_{t+1}\left(d_{t+1}+q_{t+1}\right)\right]+v_{t} \\
\lambda_{t}-\eta_{t}=E_{t}\left[\lambda_{t+1} R\right]
\end{gathered}
$$

$U_{c_{t}^{T}}(\cdot)$ and $U_{c_{t}^{N}}(\cdot)$ denote the lifetime marginal utilities of date-t consumption of tradables and nontradables respectively (including the effects of consumption changes on the infinite stream of subjective discount rates), and $\lambda_{t}, \eta_{t}$, and $v_{t}$ are the nonnegative Lagrange multipliers on the budget constraint, the margin constraint, and the short-selling constraint respectively.

Given the optimality conditions for $\alpha_{t+1}$ and $b_{t+1}$, we can derive the following two key asset pricing conditions: 


$$
\begin{gathered}
E_{t}\left[R_{t+1}^{q}-R\right]=\frac{\eta_{t}(1-\kappa)-v_{t} / q_{t}-\operatorname{cov}_{t}\left(\lambda_{t+1}, R_{t+1}^{q}\right)}{E_{t}\left[\lambda_{t+1}\right]} \\
q_{t}=E_{t}\left(\sum_{i=0}^{\infty}\left[\prod_{j=0}^{i}\left(E_{t}\left[R_{t+1+j}^{q}\right]\right)^{-1}\right] d_{t+1+i}\right)
\end{gathered}
$$

where the sequence $\left[R_{t+1+j}^{q}\right]$ is given by equation 13 Equation 13 is the model's equity premium, and equation 14 represents the forward solution for equity valuation from the perspective of the small open economy. Notice that this condition can also be expressed in the more familiar form using stochastic discount factors, adjusted for the shadow values of financial frictions, to represent the pricing kernel (see Mendoza and Smith (2006)).

\subsubsection{Foreign Securities Firms}

Foreign securities firms are modeled in the same way as in Mendoza and Smith (2006). They maximize the present discounted value of dividends paid to their global shareholders, facing trading costs that are quadratic in the volume of trades (see Aiyagari and Gertler (1999)) and in a fixed recurrent cost. These costs represent the disadvantaged position from which foreign traders operate relative to domestic agents, which may result from informational frictions, or from institutional features or government policies that favor domestic residents. The recurrent cost represents fixed costs for participating in an emerging equity market that foreign traders incur just to be ready to trade, even if they do not actually trade in a given period.

Foreign traders choose $\alpha_{t+1}$ for $t=0, \ldots, \infty$ so as to maximize the value of foreign securities firms per unit of capital:

$$
D / K=E_{0}\left[\sum_{t=0}^{\infty} M_{t}^{*}\left(\alpha_{t}^{*}\left(d_{t}+q_{t}\right)-q_{t} \alpha_{t+1}^{*}-q_{t}\left(\frac{\phi}{2}\right)\left(\alpha_{t+1}^{*}-\alpha_{t}^{*}+\theta\right)^{2}\right)\right]
$$

where $M_{0}=1$ and $M_{t}^{*}$ for $t=1, \ldots, \infty$ are the exogenous marginal rates of substitution between date-t consumption and date- 0 consumption for the world's representative consumer. For simplicity, we set $M_{t}^{*}=R_{t}^{-1}$. Trading costs are given by $q_{t}(\phi / 2)\left(\alpha_{t+1}^{*}-\alpha_{t}^{*}+\theta\right)^{2}$. The recurrent cost is $\theta$ and $\phi$ 
is an adjustment cost coefficient that determines the price elasticity of the foreign trader's demand for equity, as shown below. Note that $\theta$ induces an asymmetry in the manner in which trading costs operate. With $\theta=0$, the total cost of increasing or reducing equity holdings by a given amount is the same, but with $\theta>0$ the total cost of reducing equity holdings is higher.

An important implication of the incompleteness of asset markets is that, despite financial globalization, the stochastic sequences of $M_{t+1+i}^{*}$ and $M_{t+1+i}$ for $i=0, . ., \infty$, are not equalized. With complete markets, or under perfect foresight, both sequences are equal to the reciprocal of $\mathrm{R}$ (compounded i periods). Under uncertainty and incomplete markets, however, domestic stochastic discount factors are endogenous and reflect the effects of financial frictions.

The first-order condition of the above problem yields the following "partial adjustment" asset demand function:

$$
\alpha_{t+1}^{*}-\alpha_{t}^{*}=\frac{1}{\phi}\left(\frac{q_{t}^{f}}{q_{t}}-1\right)-\theta
$$

where we define the "fundamentals price" $q_{t}^{f} \equiv E_{t}\left(\sum_{i=0}^{\infty} M_{t+1+i}^{*} d_{t+1+i}\right)$. The key implication of this demand function is that foreigners only buy more domestic equity when the market price falls sufficiently below the fundamentals price (i.e. $\alpha_{t+1}^{*}-\alpha_{t}^{*}>0$ requires $\left.\left(\frac{q_{t}^{f}}{q_{t}}\right)>(1+\theta \phi)\right)$.

The behavior of the "fundamentals" price differs from that in the Mendoza and Smith (2006) setup because, as explained earlier, in this model the stream of dividends is affected by the endogenous equilibrium dynamics of the nontradables price and output. Because of this, in fact it is not very appropriate to call it a "fundamentals" price in this model. Intuitively, if dividends fall when the credit constraint binds because of the adverse effects on nontradables price and output, the "fundamentals price" also falls, but this means that at equilibrium, the actual equity price has to fall even more to support a given change in equity holdings than it would if the fundamentals price were invariant to the financial frictions.

\subsubsection{Asset Pricing Dynamics of Financial Globalization}

The asset pricing conditions of the small open economy and the foreign traders' asset demand function are helpful for providing some intuition about the transitional dynamics of asset prices triggered by financial integration. 
First, it is straightforward to infer from eq. 13 that, on impact, financial openness induces two effects on the agents of the small open economy that push down on expected equity returns. First, the risk-free rate drops as agents can now borrow from the infinitely-elastic global supply of credit. Second, the risk premium drops, because the improved ability to smooth consumption by borrowing from abroad makes the covariance between marginal utility and equity returns "less negative." In turn, lower expected returns imply lower discount rates on the stream of expected future dividends and thus higher equity prices.

There are also indirect effects on the asset valuations of domestic agents operating via the expected sequence of the price of nontradables, $p_{t+1+i}^{N}$, which are less straightforward. On impact, the increased consumption of tradables that financial integration allows agents to access pushes up the price of nontradables. Producers of nontradables respond to the allocational incentives of higher prices by demanding more inputs and producing more nontradables, but at equilibrium tradables consumption rises more than nontradables consumption (since effectively tradable goods have a higher supply elasticity). The rise in nontradables prices thus increases dividends on impact, because of both the higher nontradables prices and production, and this also pushes for higher equity prices.

In addition to the above effects, there are also important effects due to the risk of financial crises. These are present since the first period in the transitional dynamics of financial integration, but they are negligible because the economy's leverage at that point is far from what is needed to trigger a financial crisis. As the transition progresses and leverage rises, the risk increases and becomes a more relevant determinant of asset prices. In a financial crisis, the binding collateral constraint induces a jump in expected equity returns because of three effects visible in eq. 13 the direct effect of the positive shadow value of collateral, the indirect effect because the credit constraint hampers consumption smoothing and thus makes the covariance term in the equity premium "more negative," and a second indirect effect because the credit constraint forces consumption to be postponed, thereby lowering the expected marginal utility of future consumption in the denominator of the equity premium expression.

A financial crisis also contributes to lower asset prices via a deflation in the price of nontradables 
and its effect on nontradables producers. During a crisis, tradables consumption falls more rapidly, again because tradable goods are more elastic, and thus the nontradables price falls. Since dividends

can be expressed as $d_{t}=(1-\psi-\zeta) p_{t}^{n} \frac{\exp \left(\varepsilon_{t}\right) L_{t}^{\psi} m_{t}^{\zeta} K^{1-\psi-\zeta}}{K}$, it follows that the response of nontradables producers lowers dividends because of both lower relative prices and lower output. Lower dividends then contribute to lower equity prices.

As the transitional dynamics triggered by financial integration evolves, the increased debt and leverage of domestic agents endogenously increases the future probability of triggering the collateral constraint and experiencing a crisis. This in turn strengthens the risk effects described above, and thus eventually induces agents to re-balance their portfolio and reduce their equity holdings, even in states in which the constraint is not actually binding. Now the foreign trader's adjustment costs to selling equity becomes relevant, because they are willing to increase their equity holdings only if the price falls. This enables the model to generate the boom-bust equity cycle observed in empirical studies of financial liberalization (Martell and Stulz (2003)), even in the absence of actual financial crises. If there is a crisis, the costs faced by foreign traders are also very important, because they determine how low prices need to go when domestic agents enter the market to fire-sale domestic assets.

\subsubsection{Competitive Equilibrium with Financial Integration}

Given the Markov process of productivity shocks and the initial conditions $\left(b_{0}, \alpha_{0}, \alpha_{0}^{*}\right)$, a competitive equilibrium with the small open economy integrated to world capital markets is defined by stochastic sequences of allocations $\left[c_{t}^{T}, c_{t}^{N}, d_{t}, m_{t}, b_{t+1}, \alpha_{t+1}, \alpha_{t+1}^{*}, L_{t}\right]_{t=0}^{\infty}$ and prices $\left[w_{t}, p_{t}^{n}, q_{t}, R_{t}^{q}\right]_{t=0}^{\infty}$ such that: (a) domestic firms maximize dividends subject to the Cobb-Douglas technology, taking factor and goods prices as given, (b) households maximize SCU subject to the budget constraint, the collateral constraint, and the short-selling constraint, taking as given factor prices, goods prices, the world interest rate and asset prices, (c) foreign securities firms maximize the expected present value of dividends net of trading costs, taking as given asset prices, and (d) the market-clearing conditions for equity, labor, and goods markets hold. 


\section{Recursive equilibrium and solution method}

We solve a recursive representation of the model over triples of $(\alpha, b, \varepsilon)$ defined in a discrete state space. The solution method is similar to the method used by Mendoza and Smith (2006). However, since in this setup the fundamentals price is endogenous (instead of just a function of exogenous shocks as in their paper, we also adapt the modifications introduced by Durdu and Mendoza (2006) in a model that had a similar feature of an endogenous fundamentals price, but in their case due to the presence of government funded price guarantees. In particular, we start by using $\hat{G}(\alpha, b, \varepsilon)$ as a conjectured fundamentals pricing function, then define a Bellman equation that solves the model conditional on this conjecture, and then we iterate to convergence so that the conjecture is accurate in the final solution.

Conditional on a given $\hat{G}(\alpha, b, \varepsilon)$, the recursive equilibrium of the domestic economy with financial integration is represented by the following dynamic programming problem:

$$
V(\alpha, b, \varepsilon ; \hat{G})=\max _{\alpha^{\prime}, b^{\prime}, c^{T}, c^{N}}\left[\frac{c\left(c^{T}, c^{N}\right)^{1-\sigma}-1}{1-\sigma}+\exp \left(-\beta\left[\operatorname{Ln}\left(1+c\left(c^{T}, c^{N}\right)\right)\right]\right) E\left[V\left(\alpha^{\prime}, b^{\prime}, \varepsilon^{\prime}\right)\right]\right]
$$

subject to:

$$
\begin{aligned}
c^{T} & =y^{T}+[\zeta+(1-\psi-\zeta)(1-\alpha)] p^{n} \exp (\varepsilon) L^{\psi} m^{\zeta} K^{1-\psi-\zeta}+\left(\frac{\hat{G}(\alpha, b, \varepsilon) K}{1+\phi\left(\alpha-\alpha^{\prime}+\theta\right)}\right)\left(\alpha-\alpha^{\prime}\right)-b^{\prime}+b R \\
c^{N} & =\exp (\varepsilon) L^{\psi} m^{\zeta} K^{1-\psi-\zeta} \\
p^{n} & =\left(\frac{1-z}{z}\right)\left(\frac{c^{T}}{\exp (\varepsilon) L^{\psi} m^{\zeta} K^{1-\psi-\zeta}}\right)^{1+\mu} \\
p^{m *} & =\zeta p^{n} \exp (\varepsilon) L^{\psi} m^{\zeta-1} K^{1-\psi-\zeta} \\
b^{\prime} & \geq-\kappa\left(\frac{\hat{G}(\alpha, b, \varepsilon) K}{1+a\left(\alpha-\alpha^{\prime}+\theta\right)}\right) \alpha^{\prime} \\
\alpha & \geq \chi
\end{aligned}
$$

Assuming that factor demands are given by standard marginal productivity conditions, the 
constraints on this problem are: (1) the resource constraint in tradables, (2) the market-clearing condition for nontradables, (3) the optimality condition that sets the equilibrium price of nontradables equal to the sectoral marginal rate of substitution in consumption, (4) the optimality condition for demand of imported inputs, (5) the borrowing constraint, and (6) the short selling constraint $(-\infty<\chi<1)$. In $(1)$ and $(5)$, we imposed market clearing and used the inverse of the foreign traders' demand function to replace the equity price. For each $\varepsilon$, each set of pairs $\left(\alpha, \alpha^{\prime}\right)$, $\left(b, b^{\prime}\right)$ in the state space, and given the conjectured $\hat{G}(\alpha, b, \varepsilon)$, we can solve the system of equations implied by these constraints for recursive functions that determine $c^{T}, c^{N}, p^{n}, m$ as functions of the state variables $(\alpha, b, \varepsilon)$,

The solutions of the above problem are represented by the optimal decision rules $\alpha^{\prime}(\alpha, b, \varepsilon)$ and $b^{\prime}(\alpha, b, \varepsilon)$ and the associated optimal consumption plans. The problem is solved by value function iteration using an acceleration routine that splits each set of $n$ iterations so that the first $h$ execute the maximization step in the right-hand-side of the Bellman equation, and the remainder n-h simulate the equation forward using the last iteration's decision rules.

Given $\alpha^{\prime}(\alpha, b, \varepsilon)$ and $b^{\prime}(\alpha, b, \varepsilon)$ and the Markov process for $\varepsilon$, we can use the conditions that $q_{t}^{f} \equiv E_{t}\left(R^{*-1-i} d_{t+1+i} p_{t+1+i}^{n}\right)$ and $d_{t}=(1-\psi-\zeta) p_{t}^{n} \exp \left(\varepsilon_{t}\right) m_{t}^{\zeta} K^{-\psi-\zeta}$ to calculate an "actual" fundamentals pricing function $G(\alpha, b, \varepsilon)$. Notice this reduces to a simple recursive formula (a "value function") because we use $R^{*}$ for the stochastic discount factor of the foreign traders, and since the stream of dividends can be expressed as the following recursive function $d(\alpha, b, \varepsilon)=(1-$ $\psi-\zeta) p^{n}(\alpha, b, \varepsilon) \exp (\varepsilon) m(\alpha, b, \varepsilon)^{\zeta} K^{-\psi-\zeta}$, where $p^{n}(\alpha, b, \varepsilon)$ and $m(\alpha, b, \varepsilon)$ are the optimal rules for nontradables price and imported inputs that follow from $\alpha^{\prime}(\alpha, b, \varepsilon)$ and $b^{\prime}(\alpha, b, \varepsilon)$. If $\hat{G}(\alpha, b, \varepsilon)$ and $G(\alpha, b, \varepsilon)$ differ by more than a convergence criterion, we update $\hat{G}(\alpha, b, \varepsilon)$ and solve again the value function.

It is important to note that the equilibrium represented by the solution of the above Bellman equation does not satisfy all of the competitive equilibrium conditions, because effectively it represents the allocations and prices chosen by a social planner of the small open economy who maximizes the utility of domestic agents taking into account the equity demand function of foreign 
traders and the effects of the $\alpha^{\prime}$ and $b^{\prime}$ choices on the price at which collateral is valued.7 All the private optimality conditions and market-clearing conditions of the competitive equilibrium hold, as reflected in the constraints of the Bellman equation, but the planner does not act as a price taker. This is done for computational tractability, since we need to solve the model using a nonlinear global algorithm with two occasionally binding constraints and iterating over full solutions of the Bellman equation until $G(\cdot)$ and $\hat{G}(\cdot)$ converge 8

The equilibrium we solve for can also be interpreted as a competitive equilibrium in which the small open economy's planner implements an optimal macro-prudential policy similar to those studied by Bianchi (2011) and Bianchi and Mendoza (2012), where a financial regulator internalizes the pecuniary externality by which agents fail to take into account the effect of their individual decisions on the market value of collateral ${ }^{9}$ In our setup, however, the allocations represent only a unilateral optimal policy outcome, because the domestic social planner does not internalize the welfare of foreign traders. The planner maximizes domestic welfare by choosing an equity price along the foreign trader's demand curve and taking into account how the price of collateral and the price of nontradables respond to the small open economy's debt and equity choices.

The above interpretation of the model's solution is also interesting because it is in line with the observation from the data that the surge in net debt in emerging economies since the Sudden Stops was due to both a sharp drop in private debt liabilities and to the accumulation of foreign reserves. In the model's competitive equilibrium, private agents have stronger precautionary savings incentives than agents in a model with frictionless credit markets, but still weaker than those in the equilibrium with optimal macro-prudential policy. Hence, the quantitative analysis we conduct here

\footnotetext{
${ }^{7}$ The solution of the Bellman equation matches the competitive equilibrium if we remove the collateral constraint and set $\phi=0$ (i.e. foreign traders have an infinitely elastic demand function at the level of the fundamentals price). Thus, in states where the constraint is far from binding and since the calibrated value of $\phi$ is low, the solution we compute should be close to the competitive equilibrium.

${ }^{8}$ In their setup with an exogenous fundamentals price, Mendoza and Smith (2006) showed that, as long as $\phi$ is low, this approach yields solutions quantitatively similar to those of the full competitive equilibrium, which takes significantly longer to solve. This is because at low values of $\phi$ the demand function of foreign traders becomes highly elastic around the fundamentals price, and thus the monopolic power implied by the fact that the planner internalizes their demand function becomes quantitatively negligible.

${ }^{9}$ In their papers, a financial regulator who internalizes this externality carries less debt and leverage than private agents to reduce the risk of crises and make them less severe when they occur. Moreover, the regulator can decentralize its allocations as a competitive equilibrium using a variety of state-contingent taxes, capital requirements, or constraints on loan to value ratios.
} 
incorporates incentives for portfolio rebalancing that consider both private agents' precautionary behavior and policy incentives for precautionary accumulation of foreign reserves to manage pecuniary ex-ternalities. The drawbacks are that the policy is only unilaterally optimal, as mentioned above, and that we will not be able to isolate what fraction of the total predicted change in bond holdings is due to the original precautionary savings incentives of private agents in the competitive equilibrium and what fraction is due to the fact that the equilibrium we solve for takes into account pecuniary externalities.

\subsection{Transitional Dynamics of Financial Integration}

The decision rules and the Markov process of the exogenous shocks can be used in the usual way to compute the model's stochastic steady state under financial integration. This steady state is characterized by the long-run unconditional distribution that results from the fixed point of the following one-step (from t to $\mathrm{t}+1$ ) law of motion of conditional probabilities of triples in the state space $(\alpha, b, \varepsilon)$.

$$
p r_{t+1}\left(\alpha^{\prime}, b^{\prime}, \varepsilon^{\prime}\right)=\sum_{\varepsilon} \sum_{\left\{\alpha: \alpha^{\prime}=\alpha^{\prime}(\alpha, b, \varepsilon)\right\}} \sum_{\left\{b: b^{\prime}=b^{\prime}(\alpha, b, \varepsilon)\right\}} \sum \operatorname{pr}_{t}(\alpha, b, \varepsilon) \pi\left(\varepsilon^{\prime} \mid \varepsilon\right)
$$

This law of motion induces the $\mathrm{t}+1$ conditional probabilities by combining the decision rules for bonds and equity with the exogenous Markov process of TFP. Of particular importance for our analysis are the long-run averages for bonds and equity implied by this distribution, which capture the effects of financial integration on the long-run portfolio of external assets 10

To characterize the transitional dynamics induced by financial integration, we compute forecast functions of the equilibrium Markov processes of the relevant endogenous variables, conditional on initial conditions that correspond to those of the economy with a closed capital account ( $\alpha=1$ and $b=0)$ and the average state of TFP $\varepsilon=0$. Thus, we are solving for the transitional dynamics of an experiment in which financial opening is done in once-and-for-all, unanticipated fashion as of date 0 . The optimal decision rules $\alpha^{\prime}(\alpha, b, \varepsilon)$ and $b^{\prime}(\alpha, b, \varepsilon)$, and the sequence of conditional distributions

\footnotetext{
${ }^{10}$ It is critical to use the proposed nonlinear global solution method to solve for the decision rules and the stochastic steady state because of the precautionary savings effects at work in the model, and because of the potentially strong nonlinearities that are present when the collateral constraint binds.
} 
of $(\alpha, b, \varepsilon)$ generated by the law of motion mentioned above (for the autarky initial conditions $(1,0,0))$ are used to generate the forecast functions. These forecast functions trace the projected dynamics of the variables as they converge to their corresponding averages in the stochastic steady state under financial globalization, preserving all the non-linear aspects of the model's stochastic equilibrium.

\section{Quantitative results}

This section studies the quantitative predictions of the model regarding the transitional dynamics of financial integration. The analysis starts by pinning down the values of the model's parameters following a calibration applied to Mexican data.

\subsection{Functional forms and baseline calibration}

The numerical analysis uses these standard functional forms for preferences and technology.

$$
\begin{gathered}
F\left(K, L_{t}, m_{t}\right)=\exp \left(\varepsilon_{t}\right) L_{t}^{\psi} m_{t}^{\zeta} K^{1-\psi-\zeta} \equiv y_{t}^{N} \\
u\left(c_{t}\right)=\frac{\left[c_{t}\right]^{(1-\sigma)}-1}{1-\sigma} \\
\nu\left(c_{t}\right)=\beta\left[\operatorname{Ln}\left(1+c_{t}\right)\right] \\
c\left(c_{t}^{T}, c_{t}^{N}\right)=\left[z\left(c_{t}^{T}\right)^{-\mu}+(1-z)\left(c_{t}^{N}\right)^{-\mu}\right]^{-1 / \mu}
\end{gathered}
$$

The parameters $\psi, \zeta$, and $(1-\psi-\zeta)$ are the factor shares in production of nontradables for labor, imported inputs, and capital respectively. $\sigma$ is the coefficient of relative risk aversion, $\beta$ is the semi-elasticity of the rate of time preference. $0<\beta \leq \sigma$ is required to satisfy the conditions identified by Epstein (1983) to ensure that SCU yields well-behaved dynamics. $\mu$ sets the elasticity of substitution between tradables and nontradables, which is equal to $1 /(1+\mathrm{mu})$, and $z$ represents 
the CES weighting factor.

The calibration follows closely Mendoza (2002), which calibrates a model with tradables and nontradables for Mexico using sectoral data. Table 1 lists all of the parameter values. On the production side of the model, the steady-state (with globalization) relative price of nontradables, the world price of intermediate goods and total GDP in units of tradables are normalized to $p^{n}=1$, $p^{m}=1$ and $y^{T}+p^{N} y^{N}-p^{m} m=1$. Hence, the steady-state allocations can be interpreted as ratios relative to total GDP in units of tradables. We use the same elasticity of substitution parameter as Mendoza (2002) and Durdu et al. (2008), $\mu=0.316$, which corresponds to an estimate for Mexico obtained by Ostry and Reinhart (1992).

The share of imported input costs to gross output of nontradables is $\zeta=0.2$. In the deterministic steady state, this factor share yields a ratio of imported inputs to total GDP of $13 \%$, which matches the ratio for Mexico reported in Mendoza (2006). Given Durdu et al. (2008) estimates of the sectoral consumption-GDP ratios in Mexican data, it follows that $z=0.341$.

The Markov process of productivity shocks for the nontradables sector is set so that the standard deviation and first-order autocorrelation of GDP match the standard deviation and first-order autocorrelation of the HP-filtered quarterly cyclical component of Mexico's average GDP reported in Mendoza (2006). In terms of the simple persistence, this requires $\varepsilon_{H}=0.01785$ and $\vartheta=0.683$.

The calibration is set to yield a deterministic stationary state that replicates Mexico's 1970-95 average GDP shares of private consumption, net exports, investment, and government expenditures at current prices. For the model to mimic the consumption and net export shares in the Mexican data, it is necessary to make adjustments for investment and government expenditures. This is done by adding an autonomous (time and state invariant) level of private expenditures which is set equal to 0.328 . The capital stock is normalized at $K=1$ without loss of generality. Mexican data from the System of National Accounts yield an average labor income share for the period 1988-96 of 0.341. Consistent with estimates from many countries however, we adopted a labor share of $\psi=0.65$. Steady-state consumption is then calculated using steady-state output and the requirement that the consumption-GDP ratio matches the average from Mexican data (0.684). The coefficient of relative risk aversion and the gross real interest rate are set to standard RBC values: $\sigma=2.0$ and 
$R=(1.059)^{1 / 4}$. Finally, given $c$, the value of the time preference elasticity $\beta$ is derived from the steady-state Euler equation for bonds, which implies $\beta=\operatorname{Ln}(R) / \operatorname{Ln}(1+c)=0.187$.

While there is a unique solution for aggregate savings in the deterministic steady state, the portfolio decision over equity and bonds is indeterminate (in the stochastic model it is not because the assets are different in risk and return properties). This makes the calibration of the financial frictions challenging. For the baseline economy with financial frictions we set $\phi=0.2, \theta=0.0001$, and $\kappa=0.15$. Consistent with Mendoza and Smith (2006) we choose an adjustment cost parameter of $\phi=0.2$, which implies a relatively high price elasticity of foreigner traders demand at 5 , and therefore helps reduce the approximation error due to the assumption that the domestic social planner has monopolic power in the global market for the domestic equity. $\theta=0.0001$ was chosen to insure that the fixed cost of trading was less than $0.1 \%$ of the steady state equity price. In the model without the collateral constraint the highest debt to equity ratio is roughly 20 percent. Therefore, we chose $\kappa=0.15$, constraining the leverage ratio to just under 15 percent. Households face a short-selling constraint $\alpha_{t} \geq \chi \cdot \chi=0.75$ can be interpreted as a constraint stating that only a fraction of the capital stock of the emerging economy is tradable in international equity markets. Because these financial frictions are difficult to measure, we use sensitivity analysis to evaluate the relative importance of each friction for the main results.

\section{Table 1: Parameter Values in Baseline Calibration}

\begin{tabular}{clc} 
Notation & Parameter $/$ Variable & Value \\
\hline$\beta$ & Rate of time preference elasticity & 0.187 \\
$\sigma$ & Coefficient of relative risk aversion & 2.000 \\
$\mu$ & Elasticity exponent in CES Preferences & 0.316 \\
$z$ & CES weight of tradable consumption & 0.341 \\
$\kappa$ & Collateral coefficient & 0.150 \\
$\psi$ & Share of labor in gross output & 0.650 \\
$\zeta$ & Share of imported inputs & 0.200 \\
$R$ & Gross world interest rate & 1.059 \\
$p^{m}$ & Price of imported inputs & 1.000 \\
$A^{T}$ & Lump-sum absorption of tradables & 0.043 \\
$A^{N}$ & Lump-sum absorption of nontradables & 0.176 \\
$\phi$ & Portfolio adjustment cost coefficient & 0.200 \\
$\theta$ & Fixed trading costs & 0.0001 \\
\hline
\end{tabular}




\subsection{Baseline Transitional Dynamics}

Figure 3 shows the transitional dynamics of the key endogenous variables of the model following the unanticipated opening of the capital account at date 0 (initially zero net debt and domestic equity owned solely by domestic agents). These dynamics describe the average evolution of the variables as they go from the initial conditions under financial autarky to their new long-run averages under financial integration. The effects described earlier intuitively using the model's optimality conditions are evident in these plots. Note, however, that these dynamics do not show the dynamics of a financial crisis, because crisis dynamics correspond to the forecast functions conditional on an initial state in which the collateral constraint binds and the reversal in net exports is sufficiently large to correspond to a Sudden Stop (instead of the financial autarky steady state). Crisis states are included in Figure 3 as we take averages at each date of the transition, if the crisis probability is positive on that date, but they are averaged together with non-crises states which have much higher probability. 11

The dynamics of financial integration are characterized by a tilting of the consumption profile, with consumption rising on impact relative to the financial autarky average, in response to the new borrowing ability of the economy, but falling to a lower long-run average at the end of the transition. This occurs because the reduced external savings of the economy imply that in the long run the trade balance must be in surplus on average, and also because preferences in the model feature an endogenous rate of time preference that is an increasing function of consumption. As the risk-free rate drops, the long-run rate of time preference falls, which requires a fall in consumption. 12

The lowering of $\mathrm{R}$ that results from financial integration gives agents an incentive to borrow in order to smooth tradables consumption, and because of the CES consumption aggregator this pushes for increased consumption of nontradables as well. Hence, on impact, $c, c^{T}$, and $c^{N}$ all rise relative to their former steady states (see Panel (A)). Moreover, the consumption profiles are tilted

\footnotetext{
${ }^{11}$ Mendoza and Smith (2006), Durdu et al. (2008), and Mendoza (2010) show quantitative results for crisis dynamics produced by collateral constraints similar to the one present in this paper.

${ }^{12}$ This impatience effect is quantitatively small and is not necessary for consumption tilting. Even with standard preferences, under incomplete markets a fall in the risk-free rate reduces precautionary savings, leading to higher average debt and lower average consumption.
} 
in favor of initial consumption, because the lower $\mathrm{R}$ means that in the long run $c^{T}$ must converge to a lower average than under financial autarky, since a long-run trade surplus is required to service the debt accumulated during the transition (see Panel F). In turn, the larger long-run average debt under financial integration results from two effects: First, the long-run endogenous rate of time preference falls as $\mathrm{R}$ falls, and this implies that long-run $c$ has to fall, which is attained partly by lowering long-run $c^{T}$ and increasing debt. Second, under uncertainty, precautionary savings incentives are weakened when the rate of interest falls, and thus the economy converges to higher debt as $\mathrm{R}$ falls 13

The tilted consumption profile also implies that in the long run the relative price of nontradables falls. The movements in $c^{T}$ are larger than those in $c^{N}$ because the supply of the latter is less elastic. Hence, on impact $c^{T}$ rises more than $c^{N}$, which leads to an initial increase in the price of nontradables and a real appreciation, while in the long run the economy converges to a lower average of $c^{T}$ than $c^{N}$, and hence a lower price of nontradables and a depreciated real exchange rate (see Panels (A) and (B)). These effects are not as strong as they would be in a two-sector endowment economy, because producers of nontradables demand more intermediate goods and increase supply as the price rises. The lower nontradables price yields a lower long-run equity price, as it drives dividends from the nontradables sector to a lower long-run average.

The dynamics of the equity price in Panel (C) also reflect the effects described in the previous Section. On impact, $q$ rises because of (a) the reduction in projected asset returns driven by the lowering of the risk-free rate and the reduction in the risk premium, as the covariance between asset returns and marginal utility becomes less negative due to increased ability to smooth consumption; and (b) higher projected dividends from the nontradables sector, because of the direct and indirect effects of higher $p^{N}$. This also explains why on impact, and for about 15 periods in the initial transition, domestic agents hold on, on average, to 100 percent of domestic equity (see Panel (D)), since during this period they actually would like to hold more equity, but the fact that foreign

\footnotetext{
${ }^{13}$ The first effect is due to the preferences with endogenous rate of time preference and hence would be present even without uncertainty, although uncertainty weakens it because of precautionary savings. In contrast, the second effect would still be at work even with standard preferences, because lowering $\mathrm{R}$ further away from a constant rate of time preference also strengthens precautionary savings and leads to lower average bond holdings, as is typical in incomplete markets models.
} 
Figure 3: Transitional Dynamics for Key Macro Variables

(A.) Consumption

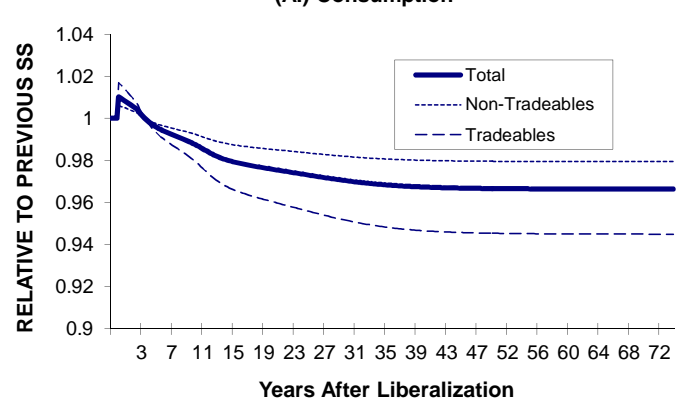

(C.) Equity Price

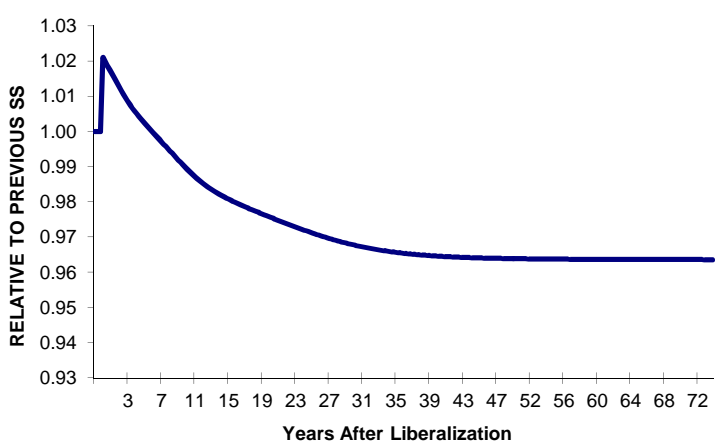

(E.) Current Account

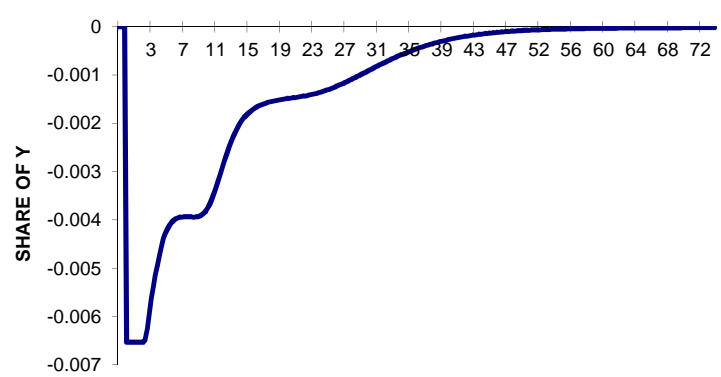

(G.) Probability Margin Constraint Binds

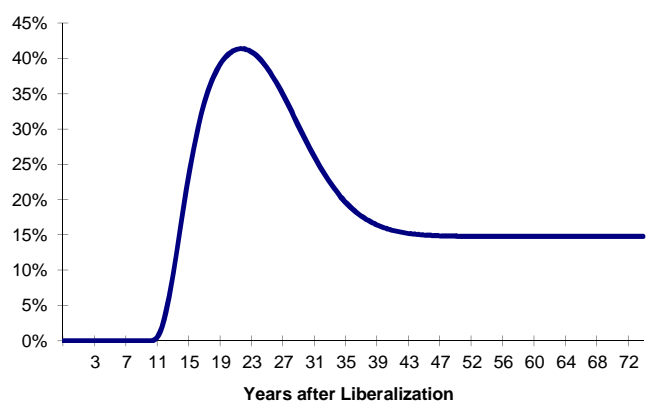

(B.) Price of Non-Tradeables to Tradeables

$1.07 \mathrm{E}+00$

$1.06 \mathrm{E}+00$

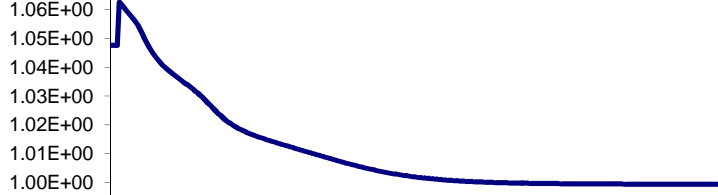

$1.00 \mathrm{E}+00$

9.80E-01

$9.70 \mathrm{E}-01$

$9.60 \mathrm{E}-01$

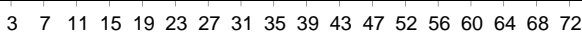
Years After Liberalization

(D.) Domestic Equity Ownership

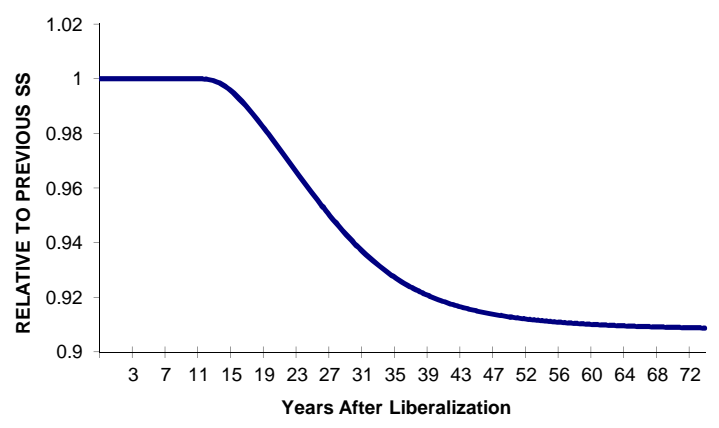

(F.) Debt Position

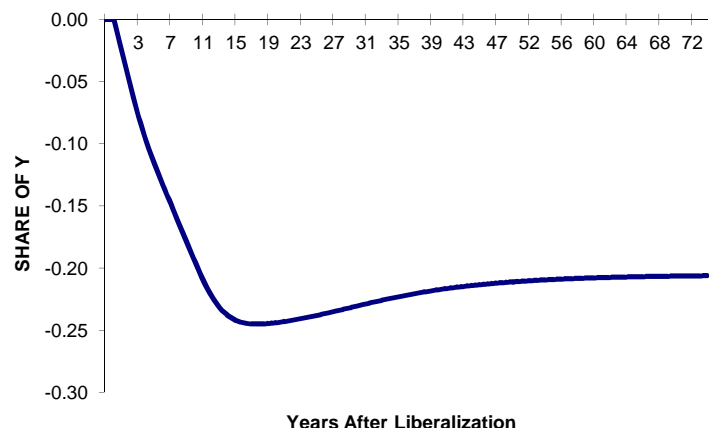

(H.) Debt to Equity Ratio

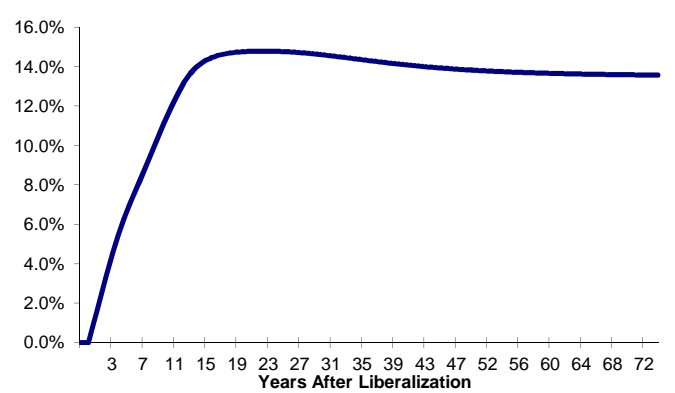


traders are not allowed to go short prevents it. Hence, the fundamentals price and the market price move together to clear the equity market so that the foreign traders' demand function also yields a constant equity position.

The equity price declines after the initial rise and over the long run converges to a lower price. This occurs in part because of the effect of the higher risk resulting from the increased probability of financial crises (Panel $(\mathrm{G})$ ), and also because of the lower $p^{N}$, which reduces projected dividends. Moreover, the lower long-run asset price is in fact pinned down by the foreign traders' demand function, which predicts that their asset holdings settle at their average when the average price is $q=q^{f} /(\phi \theta+1)$, where $q^{f}$ falls together with the nontradables price as explained earlier.

As the riskiness of domestic equity due to the rising probability of crises increases sufficiently, and projected nontradables dividends fall with falling nontradables prices sufficiently, the economy starts re-balancing its portfolio. Hence, after about the 15th period, it starts reducing equity holdings and increasing bond holdings (i.e. reducing foreign debt). This puts further downward pressure on equity prices, because foreign traders are only able to buy the equity gradually, because of trading costs, and they do so only if the price falls sufficiently below $q^{f}$. Moreover, $q^{f}$ itself is falling as $p^{N}$ falls, which implies that the actual equity price needs to fall further in order for foreign traders to be willing to buy the equity the domestic economy is selling.

As described above, the dynamics of the crisis probability play a central role in determining the riskiness of domestic equity and the evolution of the portfolio choice and asset prices. Panel (G) shows that, since the economy starts with zero debt and 100 percent equity holdings, it also has zero leverage, and hence the probability of crisis starts at zero. Leverage builds gradually and hence the probability of hitting states where the collateral constraint binds takes about 10 periods to become positive. By then, debt is still building up but asset prices are declining and equity holdings are only marginally changing, so leverage continues to grow, and hence the probability continues to rise. This process peaks at about 25 periods after financial integration occurred, with a crisis probability of about 40 percent. Thus, the probability of a financial crisis overshoots significantly its long-run level of about 15 percent during the transition from financial autarky to financial openness.

After the peak of the crisis probability the portfolio re-balancing kicks in, the leverage ratio 
starts declining (despite a continued fall in asset prices), and the probability of hitting the collateral constraint starts to fall. In the long run, trading off the cost of precautionary savings against the benefit of reducing the risk of a financial crisis probability, the probability converges to about 15 percent. By then, portfolio re-balancing leads to a decline of nearly 10 percentage points in equity holdings, and a debt position of about $1 / 5$ th of GDP.

We can use Figure 3 to compare the model's predicted changes in the external asset portfolio with the emerging markets' GDP-weighted averages reviewed in Section 1. ${ }^{14}$ It is important to note that the positions in the data are in dollar values (i.e. the product of price and position expressed as a percent of GDP). Measured in this way, the GDP-weighted average decline in the equity position since the onset of the 1990s Sudden Stops was about 17 percentage points, very similar to the model measured from the date when the crisis probability peaked. The model does not do as well in matching the rise in holdings of bonds, because these increased by about 29 percentage points on average (GDP-weighted) across the emerging markets, compared with 3 percentage points in the model. 15 Still, both adjustments are qualitatively consistent with the data dynamics in predicting that emerging markets would re-balance their external asset portfolios sharply after the 1990s Sudden Stops. In terms of capturing the increased probability of financial crisis post financial globalization, the model suggests the most likely time for a crisis during transition is in year twelve. This matches quite closely the timing of the Sudden Stops that occurred within a decade of financial integration for the most part. (See the Appendix for a plot of the financial integration index for the emerging markets.)

The empirical literature on the asset pricing implications of financial integration documents two important stylized facts that are in line with the model's quantitative predictions about the transitional evolution of asset prices and leverage. First, equity prices tend to rise post-liberalization. Using event study analysis, both Bekaert and Harvey (2000) and Henry (2000) show that equity prices rise dramatically post-liberalization. Five years after an emerging market has liberalized, the

\footnotetext{
${ }^{14}$ While model is calibrated to a particular emerging market, Mexico, our intent is not to attempt to match the particular way in which Mexico globalized. Instead, we compare our model to the average response to all the emerging markets in order to generalize our results.

${ }^{15}$ In the data, bonds are also affected by valuation changes in the price of bonds and in exchange rates, which are absent from our model because the price of bonds is always $1 / \mathrm{R}$.
} 
Figure 4: One vs. Two Good Model

(A.) Consumption

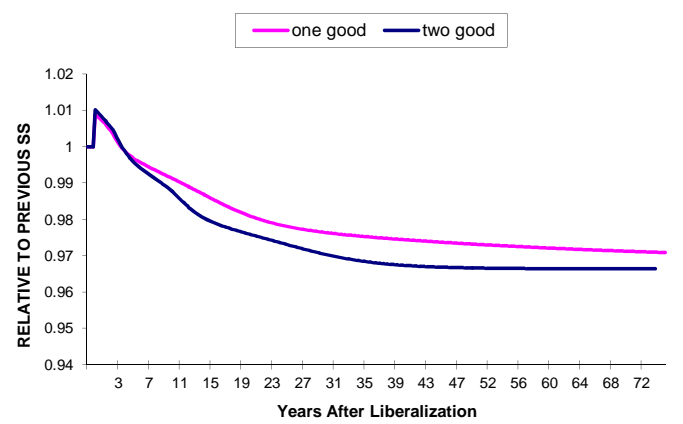

(C.) Equity Price

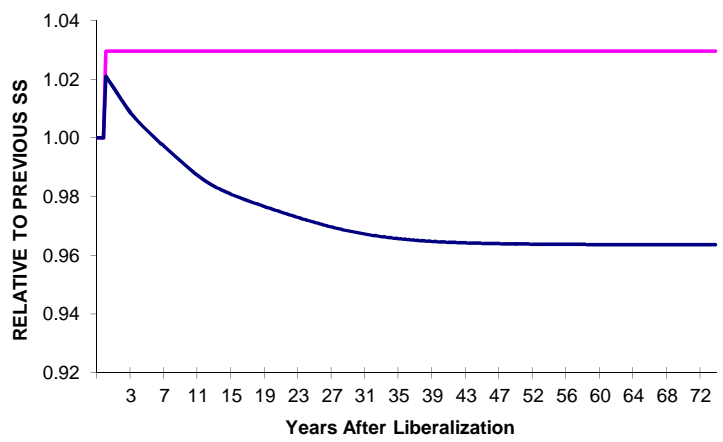

(E.) Current Account

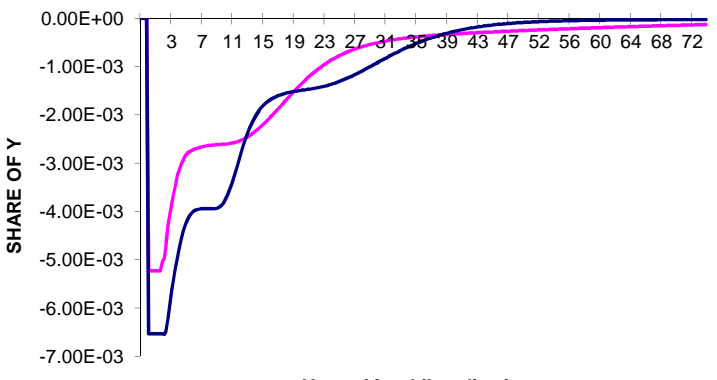

Years After Liberalization

(G.) Probability Margin Constraint Binds

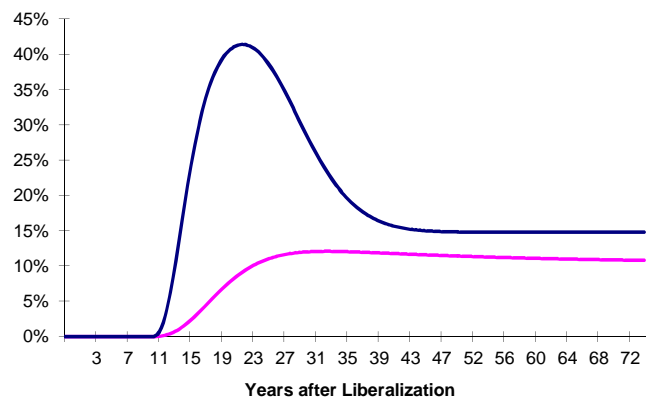

(B.) Price of Non-Tradeables to Tradeables

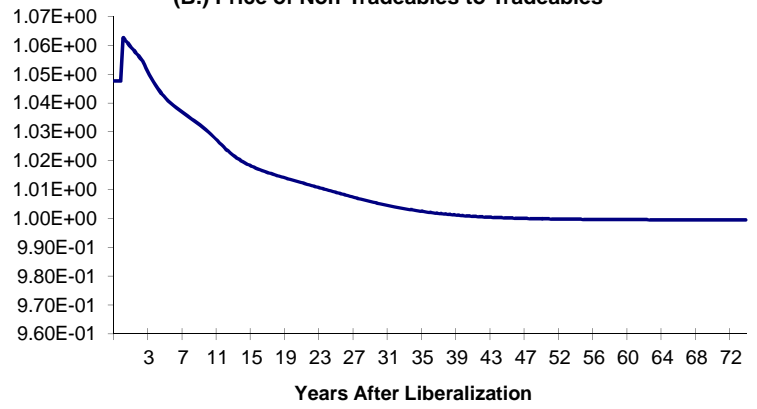

(D.) Domestic Equity Ownership

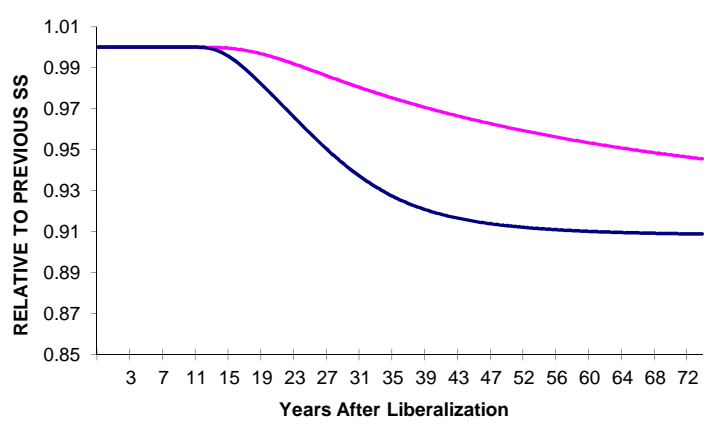

(F.) Debt Position

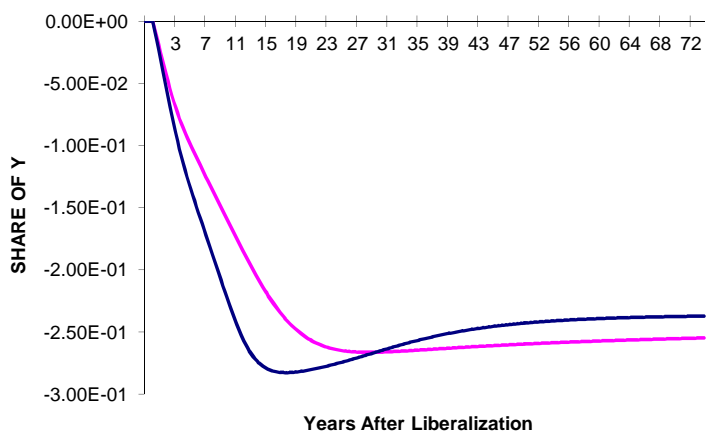

(H.) Debt to Equity Ratio

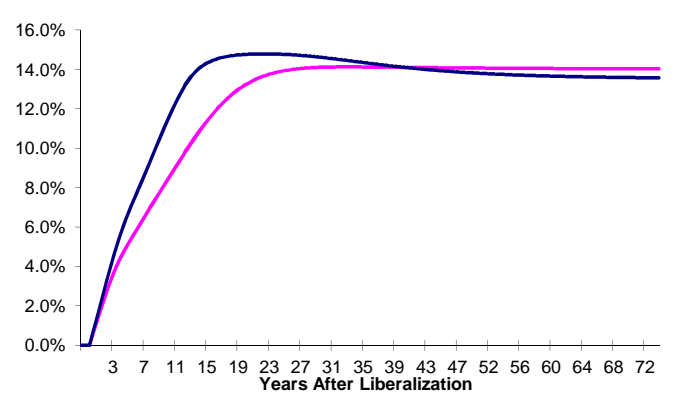


cumulative excess return using liberalization dates from Bekaert and Harvey $(2000)$ is $491 \%$ and $546 \%$ based on Henry (2000). While their estimates vary, both cite declines in the cost of capital that lead to large increases in equity prices. The second stylized fact, as documented by Martell and Stulz (2003), is that the initial rise in equity prices, like firm IPOs, is followed by a subsequent decline, suggesting an equity price boom-bust cycle post-liberalization. Martell and Stulz (2003) show that equity markets in countries liberalizing outperform those of other countries by more than $50 \%$ in the first year, but underperform by more than $20 \%$ in the fifth year after liberalization.

The model is consistent with the boom-bust equity cycle that Martell and Stulz (2003) find in their empirical examination of equity returns in liberalized economies. The decline in equity prices occurs at much slower pace than the rapid rise in prices immediately after liberalization (see Figure 3), but it is clear that they are falling prior to the rise in the crisis probability. Panel (D) shows that equity ownership holds steady until the crisis probability starts to increase, while Panel (H) shows a rapid increase in foreign debt before the rise in the crisis probability. Hence, since asset prices are falling, debt rising, and equity holding steady, the leverage ratio is rising and increasing the risk of hitting the critical level at which the constraint binds.

Financial frictions and the two-sector structure of the model play a key role in the results. To illustrate this, we conduct two sets of comparisons. First, we compare the baseline transitional dynamics induced by financial integration with those of a one-sector model (Figure 4). Second, we do a similar comparison but relative to an economy without financial frictions (Figure 5).

Figure 4 shows that the stronger financial amplification mechanism with nontradable goods results in larger effects of financial globalization on the external asset portfolio than in a onesector model, resulting in a significantly larger long-run decline in equity holdings. Debt increases less because the higher volatility and more severe crises of the two-sector model provide stronger incentives for precautionary savings. Moreover, the overshooting in the probability of crisis during the transition is much stronger in the two-sector model.

The transitional dynamics in the one-good economy are significantly different. The one-good economy is identical to the one studied in Mendoza and Smith $(2006)$. A key difference is that in their model financial frictions cannot affect production, dividends and the fundamentals price. 
As Figure 4 shows, this results in very different implications for equity prices, equity and debt positions, and the probability of hitting the collateral constraint.

The asset price rises on impact driven by the same effects of lower projected returns due to lower risk-free-rate and lower risk premium. But with dividends unaffected by financial frictions, and absent the adverse asset pricing effects of a lower long-run nontradables price, the long-run asset price remains higher than the pre-financial-integration level. The effect of increased risk of financial crisis does eventually kick in, with the crisis probability beginning to increase later in the transition, but the probability rises much less than in the two-sector model and its overshooting is much less pronounced. Equity adjusts less and at a much more gradual pace, and it converges to a longrun position about 500 basis points higher than in the two sector model. Debt grows less initially and displays a much smaller upward correction in response to increased financial crisis risk. Thus, without the two-sector specification, and its implied link between financial risk and production, the model cannot produce a boom-bust equity cycle and overshooting in the probability of crisis, and its re-balancing dynamics are much weaker.

Consider next the comparison of our baseline case versus a scenario without the credit constraint. Figure 5 shows that the consumption paths are still tilted towards the early part of the transition. This is because we still have the tilting effects induced by the lower rate of time preference and diminished precautionary savings incentives that result from the fall in $\mathrm{R}$ under financial integration. The related effects on the nontradables price and asset prices are therefore also still there. Moreover, since forecast functions show conditional averages, and in these averages the probability of crisis is relatively small, the consumption paths, price of nontradables and asset price are similar with and without frictions. The long run external portfolios, however, are very different. Without collateral constraints the economy converges monotonically to a much lower debt position, and the correction in equity holdings is less than 200 basis points. Thus, the risk of financial crises does matter for the long-run asset market structure. In fact, the emerging economy alters it precisely so that it can manage the impact of the crisis risk on the average macro dynamics. 
Figure 5: Comparison to Economy Without Collateral Constraints
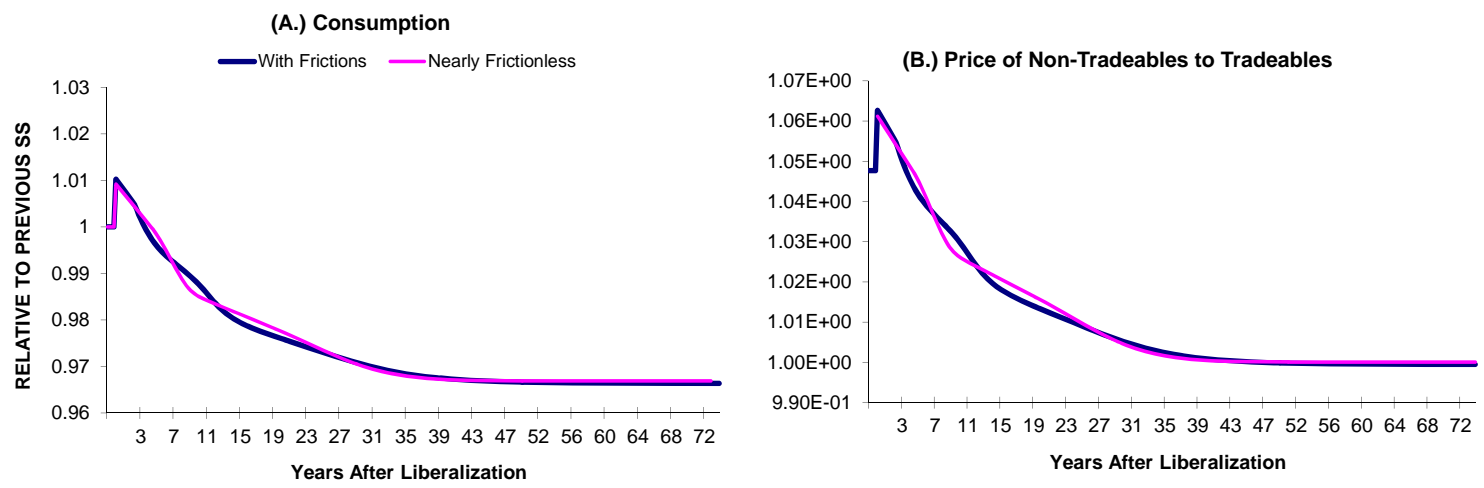

(C.) Equity Price

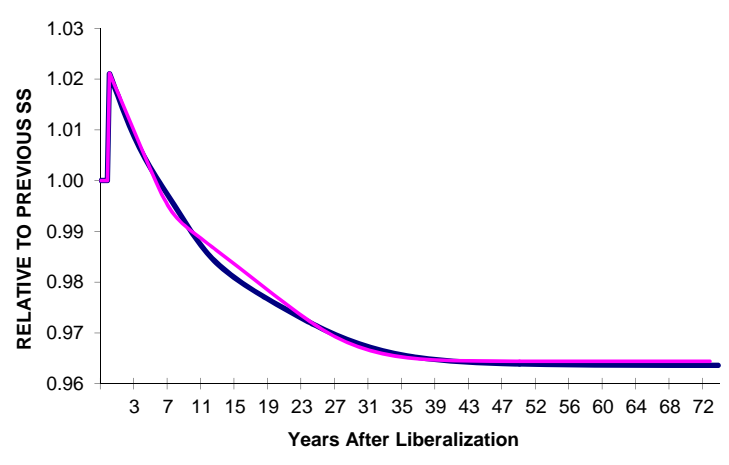

(D.) Domestic Equity Ownership

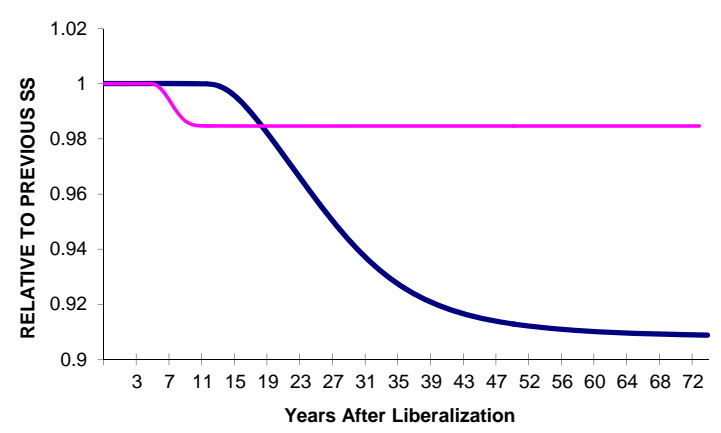

(E.) Current Account

(F.) Debt Position
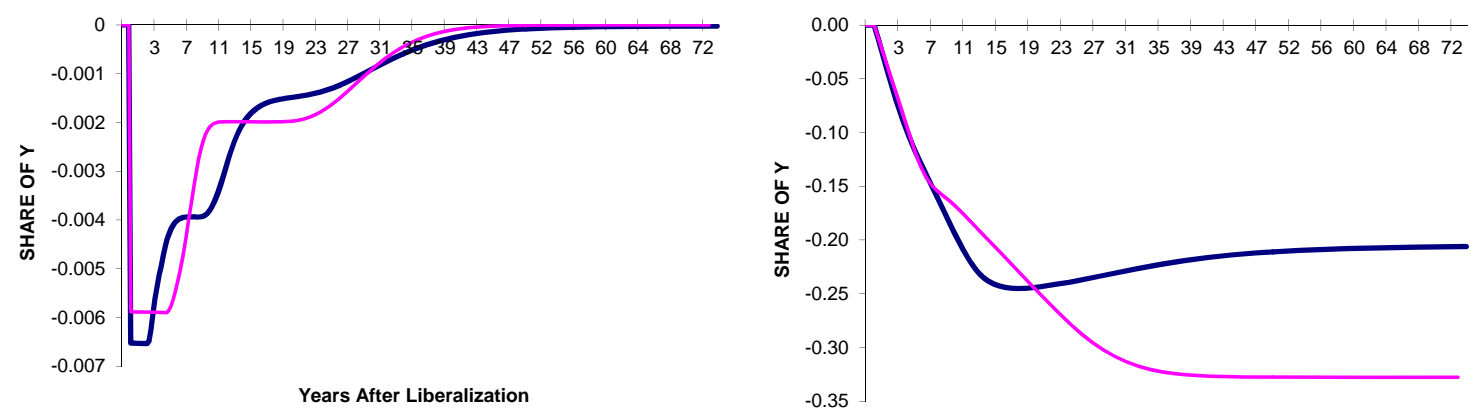

Years After Liberalization

(G.) Probability Margin Constraint Binds

(H.) Debt to Equity Ratio
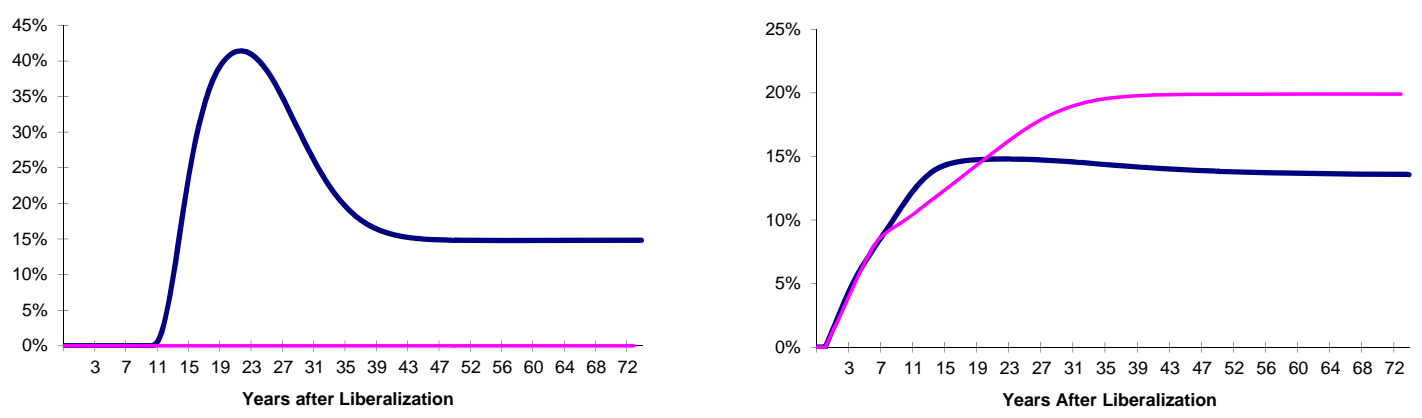


\subsection{Sensitivity Analysis}

Table 2 compares the long-run averages of the debt-to-GDP ratio and debt-to-equity ratio under four parameter specifications: The financial frictions baseline, the model without collateral constraints, and variations of the baseline with lower $(\phi=0.15)$ and higher $(\phi=0.25)$ adjustment costs.

The emerging economy takes on the largest debt position and the largest debt-equity ratio in the environment where there is no crisis risk and hence the precautionary savings incentives are the weakest. In contrast, in the baseline calibration the debt ratio and the debt-equity ratio fall to 13.1 and 8.9 percent respectively, and relative to this baseline, higher (lower) adjustment costs on foreign traders results in a higher (lower) debt and debt-equity ratios. Thus, as long as the collateral constraint is at risk of becoming binding, the economy converges to a lower debt ratio and a lower debt-equity ratio in the long run. The size of the adjustment cost matters because the long-run price is higher at lower cost parameters (recall that, from the foreign traders' demand function, the average price in the long run must satisfy $\left.q=q^{f} /(\phi \theta+1)\right)$, and thus at lower adjustment costs the domestic agents hold on to larger equity positions.

Table 2: Long Run Means of External Capital Structure Post-Financial Account Liberalization

\begin{tabular}{lcc}
\hline & $\begin{array}{c}\text { Net Debt Position } \\
\text { as a \% of GDP }\end{array}$ & $\begin{array}{c}\text { Net Debt Position } \\
\text { as a \% of Equity Position }\end{array}$ \\
\hline Without Collateral Constraints & $16.0 \%$ & $10.4 \%$ \\
Financial Frictions Baseline & $13.1 \%$ & $8.9 \%$ \\
Lower portfolio adjustment costs & $11.6 \%$ & $8.1 \%$ \\
Higher portfolio adjustment costs & $14.0 \%$ & $9.2 \%$ \\
\hline
\end{tabular}

We also conduct sensitivity analysis to evaluate the robustness of the result that there is overshooting of the probability of crisis during the transition (which implies also overshooting in leverage). Figure 6 shows the transitional dynamics of the probability of hitting the collateral constraint comparing the baseline results with four alternative specifications: lower adjustment costs on foreign traders $(\phi=0.15)$, higher recurrent costs on foreign traders $(\theta=0.001))$, a lower collateral coefficient $(\kappa=0.2)$, and a higher coefficient of relative risk aversion $(\sigma=2.5)$. 
The results show that the overshooting of the crisis probability is a feature of all the parameter variations. Significant overshooting remains with the lower adjustment costs (Panel (B)) and lower collateral coefficient (Panel (D)). In the case with lower adjustment costs, the crisis probability peaks at a much lower level than in the baseline, $25 \%$ in the 25th year after liberalization. This occurs because lower adjustment costs make it less costly for the foreign traders to buy equity, reducing the equity price volatility, and because the long-run price is higher at lower adjustment costs. Similarly, the weaker credit constraint with the lower collateral coefficient becomes binding with lower probability, so the probability peaks at a lower maximum.

With the higher recurrent trading cost (Panel $(\mathrm{C})$ ), the crisis probability climbs significantly higher during the transition, but it also converges to a higher long-run value, and thus the overshooting is significantly smaller. In this scenario, the long-run asset price converges to a lower level, which explains the higher long-run crisis probability, and the transitional peak is higher also because the higher recurrent trading cost makes it harder for foreign traders to buy the equity that domestic agents fire sale when the collateral constraint binds.

With higher risk aversion (Panel (E))the probability peaks at about half the value as in the baseline, but the overshooting is still significant (although the probability of crisis declines at a much lower pace than in the baseline). With a higher risk aversion parameter, domestic agents are likely to want to move less consumption forward and more concerned with precautionary savings, forcing the debt to equity ratio lower.

In short, both Table 2 and Figure 6 show that the main results about portfolio re-balancing and overshooting of the crisis probability are qualitatively robust to several parameter modifications. However, the quantitative characteristics of these results, including the timing at which crisis can occur and/or the probability of hitting the credit constraint peaks, are affected by parameter values. This finding can be important for explaining the heterogeneity in the timing of financial crises across various emerging markets. Sudden Stops varied a lot in their timing relative to the date of financial liberalizations and some countries liberalized without a major crisis following later on. 
Figure 6: Sensitivity Analysis

\section{(A.) Baseline}

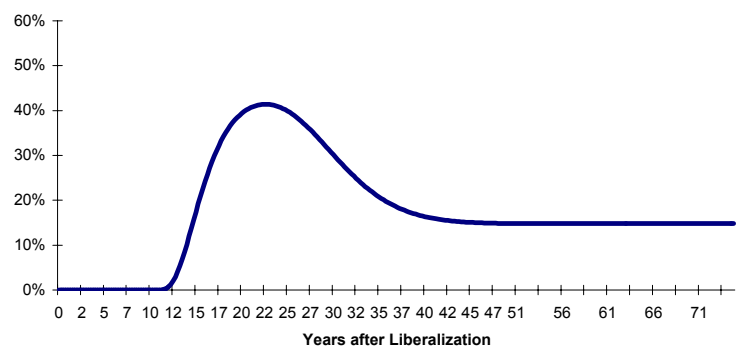

(B.) Lower Portfolio Adjustment Costs (0.15)

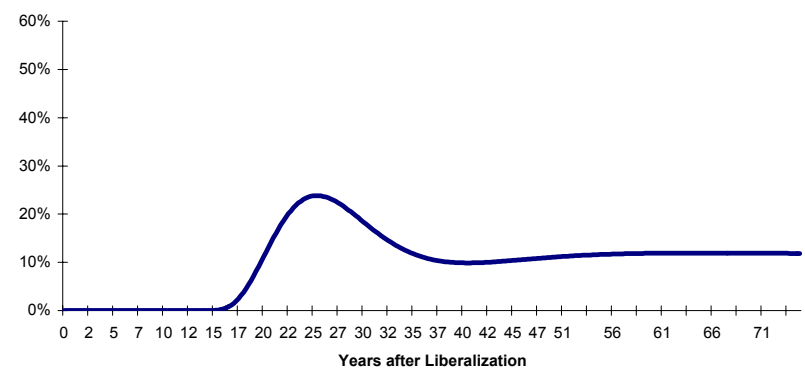

(D.) Lower Collateral Constraint (0.8)

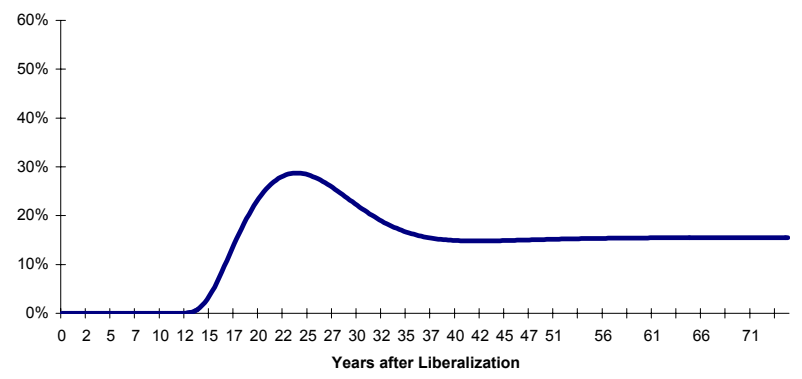

(C.) Higher Recurrent Trading Costs (0.001)

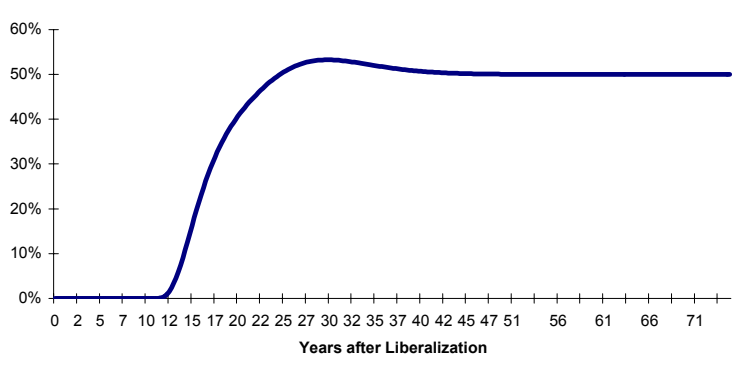

(E.) Higher Risk Aversion (2.5)

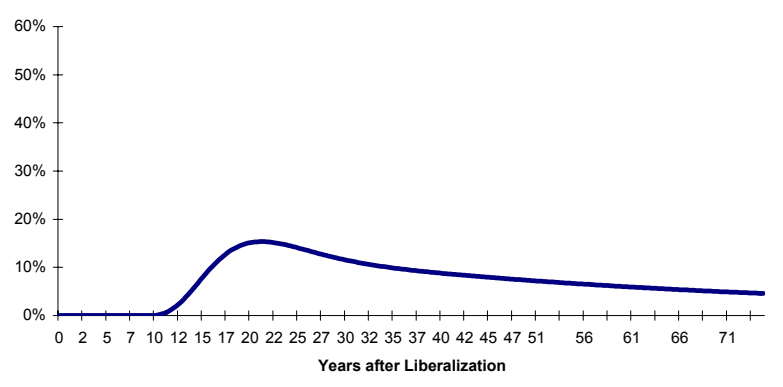




\section{Comparing Alternative Financial Integration Strategies}

The results reported in the previous Section showing that financial integration in the presence of financial frictions leads to overshooting of the crisis probability, which peaks in the early stages of transition, pose a natural follow-up question: Is it possible to address this overshooting problem by opening only partially the capital account (e.g. by allowing only trade in equity)?

In the baseline results we considered an economy that liberalized all international asset trading, in bonds and equity, in an unanticipated, once-and-for-all fashion. ${ }^{16}$ In contrast, Figure 7 and Table 3 compare the results for transitional dynamics and long-run moments under three financial integration strategies: opening only the bond market, only the equity market, or both markets simultaneously (which is the baseline assumption).

As Figure 7 shows, the financial opening strategy obviously has significant effects on the external asset portfolio, in the direction one would expect: Relative to the baseline, the debt position with bonds trading only declines more and does not display re-balancing, and with equity trading only the fall in the equity position is significantly more pronounced. Consumption and the current account, however, display smaller differences. Interestingly, with bonds trading only, there is no overshooting in the likelihood of crises. Moreover, the crisis probability is lower than in the baseline for the first 30 periods, but converges to a significantly higher long-run probability. Thus, this approach to financial integration is less likely to yield a financial crisis in the early stages of financial integration than full opening of the capital account, but more likely to do so in the long run. ${ }^{17}$ In contrast, if we only allow equity trading, by construction the probability of a crisis is zero in the model, because there is no way to borrow and build leverage in credit markets.

Table 3 compares how the method of liberalization of the financial account impacts the long run moments of the data. In terms of the means of the data, the liberalization policies deliver similar effects on consumption and equity prices, yet have differing effects on the portfolio composition

\footnotetext{
${ }^{16}$ Interestingly, in the case of Mexico, the country we calibrated the model to, financial integration was a gradual process. According to Aspe (1993), while domestic equity in Mexico was ostensibly sold to foreigners as far back as 1972, it was not until supplemental legislation was passed in 1989 that portfolio equity trading and FDI actually began.

${ }^{17}$ In this case, the borrowing constraint is for a fraction of the value of 100 percent ownership of equity holdings, because the emerging economy cannot trade equity with foreign traders, but domestic equity holdings are still useful as collateral in bond markets.
} 
Figure 7: Comparing Ways To Liberalize
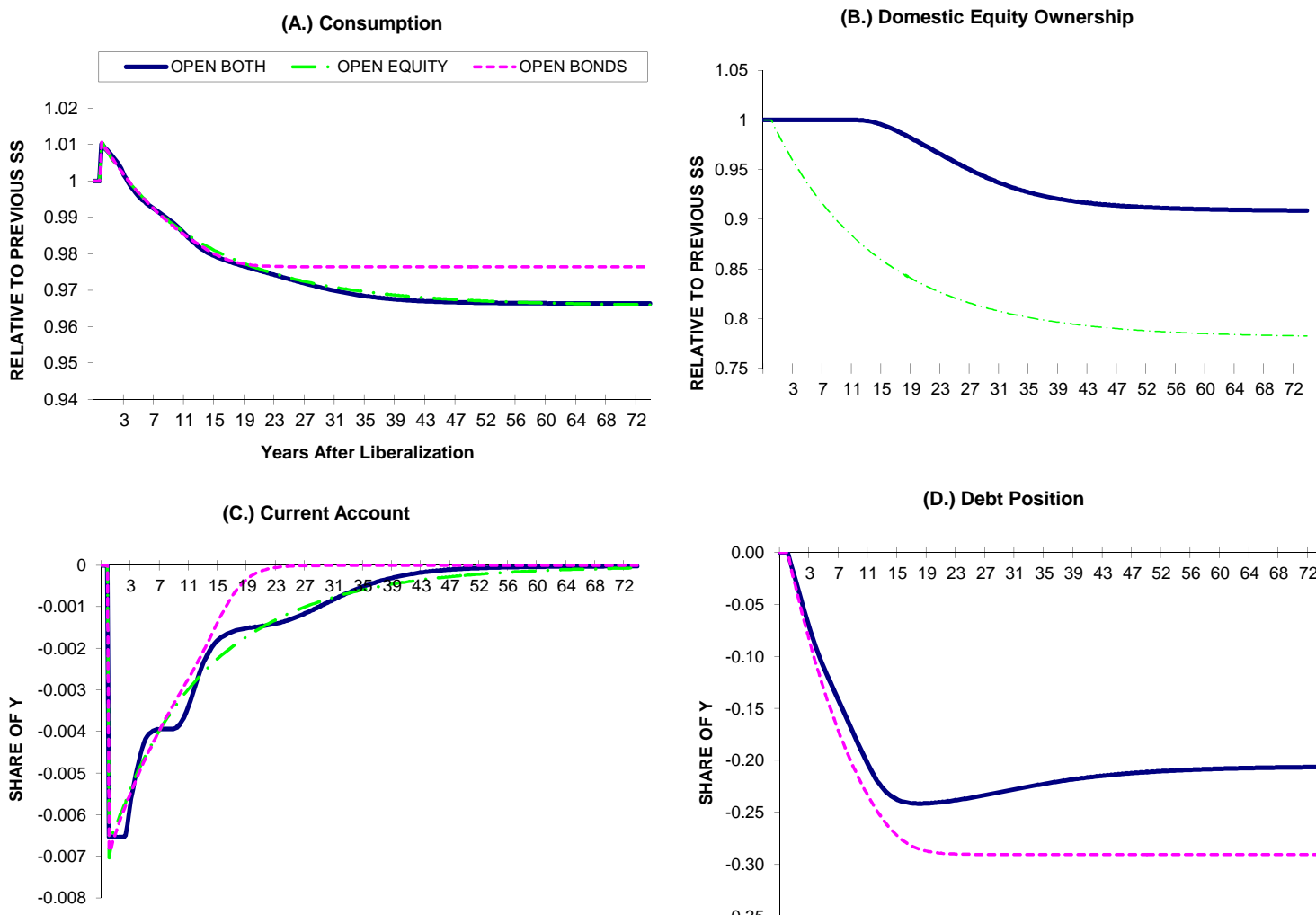

(D.) Debt Position

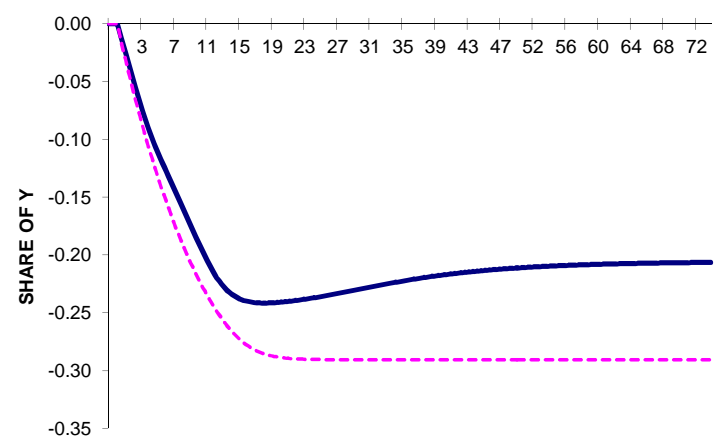

(E.) Probability Margin Constraint Binds
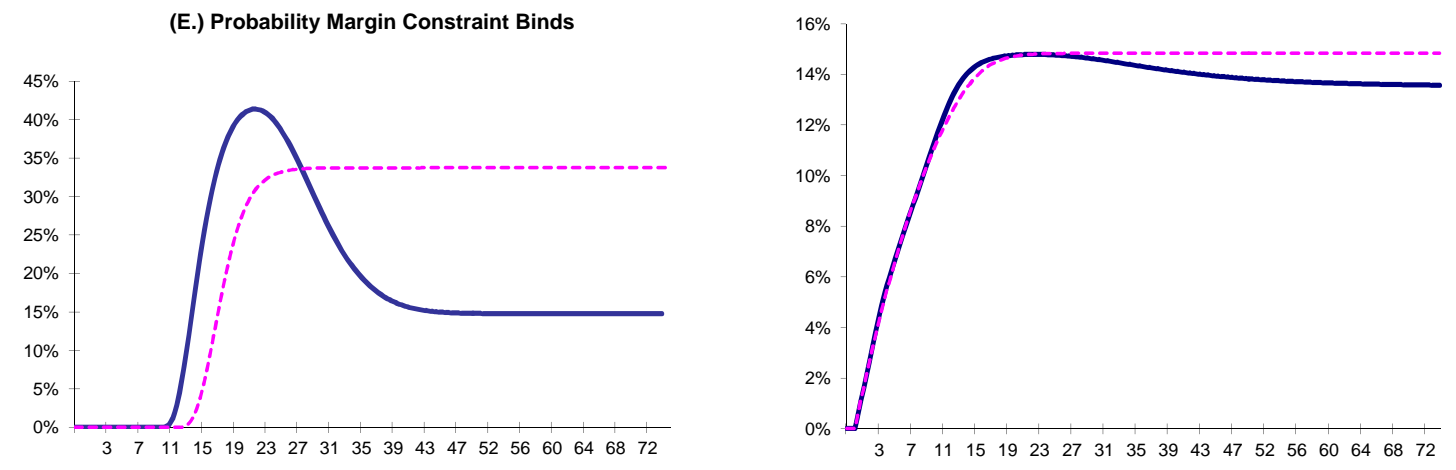
Table 3: Long Run Business Cycle Moments

\begin{tabular}{|c|c|c|c|c|c|}
\hline & mean & $\begin{array}{c}\text { standard } \\
\text { deviation } \\
(\%) \\
\end{array}$ & $\begin{array}{c}\text { standard } \\
\text { deviation } \\
\text { relative to GDP }\end{array}$ & $\begin{array}{c}\text { correlation } \\
\text { with } \\
\text { GDP } \\
\end{array}$ & $\begin{array}{l}\text { first-order } \\
\text { auto } \\
\text { correlation } \\
\end{array}$ \\
\hline \multicolumn{6}{|l|}{ I. Liberalize Just Bonds } \\
\hline GDP & 1.115 & 0.998 & 1.000 & 1.000 & 0.693 \\
\hline consumption & 0.363 & 1.841 & 1.845 & 0.999 & 0.708 \\
\hline tradeables & 0.265 & 0.516 & 0.517 & 0.936 & 0.830 \\
\hline non-tradeables & 0.432 & 2.661 & 2.667 & 1.000 & 0.693 \\
\hline equity price & 1.958 & 0.204 & 0.204 & -0.976 & 0.617 \\
\hline price of non-tradeables/tradeables & 1.014 & 2.876 & 2.883 & -0.996 & 0.661 \\
\hline current account - GDP ratio & 0.0000 & 0.088 & 0.088 & 0.726 & 0.522 \\
\hline foreign debt - GDP ratio & 0.252 & 0.515 & 0.517 & 0.896 & 0.873 \\
\hline \multicolumn{6}{|l|}{ II. Liberalize Just Equity } \\
\hline GDP & 1.115 & 0.979 & 1.000 & 1.000 & 0.692 \\
\hline consumption & 0.359 & 1.778 & 1.817 & 0.996 & 0.709 \\
\hline tradeables & 0.260 & 0.553 & 0.565 & 0.672 & 0.929 \\
\hline non-tradeables & 0.430 & 2.621 & 2.678 & 1.000 & 0.692 \\
\hline equity price & 1.921 & 0.355 & 0.362 & -0.269 & 0.909 \\
\hline price of non-tradeables/tradeables & 0.999 & 3.009 & 3.075 & -0.984 & 0.671 \\
\hline current account - GDP ratio & 0.0001 & 0.178 & 0.182 & 0.960 & 0.667 \\
\hline \multicolumn{6}{|l|}{ III. Liberalize Both } \\
\hline GDP & 1.115 & 0.961 & 1.000 & 1.000 & 0.699 \\
\hline consumption & 0.359 & 1.707 & 1.776 & 0.994 & 0.726 \\
\hline tradeables & 0.260 & 0.565 & 0.588 & 0.443 & 0.945 \\
\hline non-tradeables & 0.430 & 2.574 & 2.678 & 1.000 & 0.699 \\
\hline equity price & 1.922 & 0.332 & 0.346 & -0.301 & 0.871 \\
\hline price of non-tradeables/tradeables & 0.999 & 3.130 & 3.256 & -0.977 & 0.661 \\
\hline current account - GDP ratio & 0.000 & 0.235 & 0.244 & 0.860 & 0.642 \\
\hline debt - GDP ratio & 0.131 & 7.629 & 7.936 & 0.109 & 0.999 \\
\hline debt - equity ratio & 0.089 & 4.917 & 5.115 & 0.045 & 0.999 \\
\hline
\end{tabular}


as would be expected. Liberalization policies greatly impact the probability of a crisis and the volatility of consumption, measured by the standard deviation. Opening just equity, eliminates the probability of a debt-deflation crisis but increases consumption volatility substantially more to 1.777 , versus 1.810 in the model where both equity and debt are liberalized.

\section{Conclusions}

This paper shows that financial integration in the presence of financial frictions, as undertaken in emerging markets, causes overshooting in the probability of financial crisis during the transition, and leads to a long-run external asset portfolio characterized by a sharp decline in holdings of domestic equity and a rise in bond holdings after the crisis probability peaks. In the absence of financial frictions, the model predicts that financial integration would have produced a very small decline in equity holdings and a large increase in debt.

The overshooting in the crisis probability implies that the economy is more prone to financial crises at the point of the transition in which increases in borrowing and leverage increase the likelihood of hitting a collateral constraint, which triggers the Fisherian debt-deflation amplification mechanism. The subsequent decline in the crisis probability is the result of portfolio re-balancing, which leads the economy to reduce its holdings of domestic equity and also to reduce its debt (i.e. increase its holdings of risk free assets). Thus, the positive effects of financial liberalization in terms of reduced borrowing costs, reduced risk premia and improved consumption smoothing, are shared with the negative effects in terms on vulnerability to financial crises.

These results are in line with the observed higher frequency of crises a decade after emerging markets began to open their capital accounts, the substantial decline in their external net equity positions, and the evidence from empirical studies on a boom-bust equity cycle in emerging economies following financial liberalization. The model also predicts a rise in net holdings of riskless bonds

after the crisis probability peaks, but the size of this increase is smaller than what is observed in the data.

The analysis also shows that the results hinge on allowing financial frictions to have significant effects on dividends (i.e. "supply-side" effects). In the model, these effects follow from the fact that 
a binding collateral constraint reduces tradables consumption and lowers the price of nontradable goods, leading firms in this sector to reduce production. In turn, reduced dividends contribute to enlarge the decline in asset prices caused by asset fire sales when the collateral constraint binds, which in turn tightens access to credit further and feeds back into larger declines in the price of nontradables. A one-sector version of the model, in which this mechanism is absent, predicts a significantly smaller decline in equity holdings, and a lower peak in the probability of crisis during the transition, with almost no overshooting.

The portfolio of external assets in industrial countries followed a very different path in their post-financial integration transition, with a sharp increase in net equity holdings and a sharp drop in net debt. The 2008 crisis and the recent turmoil in Europe could imply, however, that financial frictions in industrial countries may be more relevant than anticipated, and if so, our analysis would predict a slow-moving but clear pattern of portfolio re-balancing for these countries in the future. 


\section{References}

Aiyagari, S. Rao, and Mark Gertler. 1999. “'Overreacion' of Asset Prices in General Equilibrium.” Review of Economic Dynamics 2(1), pp. 3-35.

Aizenman, Joshua, and Jaewoo Lee. 2007. "International Reserves: Precautionary versus Mercantilist Views, Theory and Evidence." Open Economies .

Alfaro, Laura, and Fabio Kanczuk. 2006. "Optimal Reserve Management and Soverign Debt." Working paper.

Arellano, Cristina, and Enrique G. Mendoza. 2003. "Credit Frictions and 'Sudden Stops' in Small Open Economies: An Equilibrium Business Cycle Framework for Emerging Markets Crises.” In Dynamic Macroeconomic Analysis: Theory and Policy in General Equilibrium, eds. Sumru Altug, Jagjit S. Chadha, and Charles Nolan, chap. 7. Cambridge, UK: Cambridge University Press, pp. $335-405$.

Aspe, Pedro. 1993. Cambridge, MA: MIT Press.

Backus, David K., Allan W. Gregory, and Stanley E. Zin. 1989. "Risk Premiums in the Term Structure: Evidence from Artificial Economies." Journal of Monetary Economics 24, pp. 371400.

Bekaert, Geert, and Campbell R. Harvey. 2000. "Capital Flows and the Behavior of Emerging Market Equity Returns." In Capital Flows and the Emerging Economies: Theory, Evidence, and Controversies, ed. Sebastian Edwards, chap. 6. NBER Conference Report, Chicago: University of Chicago Press, pp. 159-194.

Caballero, Ricardo J., and Stavros Panageas. 2006. "Hedging Sudden Stops and Precautionary Contractions." Journal of Development Economics .

Calvo, Guillermo A. 1998. "Capital Flows and Capital Market Crises: The Simple Economics of Sudden Stops." Journal of Applied Economics 1(1), pp. 35-54. 
Chinn, Menzie D., and Hiro Ito. 2007. "A New Measure of Financial Openness.” Working paper, University of Wisconsin.

Choi, Woon Gyu, Sunil Sharma, and Maria Stromqvist. 2007. "Capital Flows, Intergration, and International Reserve Holdings: The Recent Experience Experience of Emerging Markets and Advance Economies." Working paper, IMF, Washington, DC.

Christiano, Lawrence J., Christopher Gust, and Jorge Roldos. 2000. "Monetary Policy in a Financial Crisis." Unpublished manuscript.

Demirguc-Kunt, Asli, and Enrica Detragiarche. 1998. "Financial Liberalization and Financial Fragility." International Monetary Fund Working Paper no 98/83.

Durdu, Ceyhun Bora, and Enrique Mendoza. 2006. "Are asset price guraantees useful for preventing Sudden Stops?: A Quantitative Analysis of Globalization Hazard-Moral Hazard Tradeoff." Journal of International Economics .

Durdu, Ceyhun Bora, Enrique Mendoza, and Marco Terrones. 2008. "Precautionary Demand for Foreign Assets in Sudden Stop Economies: An Assessment of the New Merchantilism." Journal of Development Economics .

Epstein, Larry G. 1983. "Stationary Cardinal Utility and Cardinal Growth under Uncertainty." Journal of Economic Theory 31(1), pp. 133-152.

Glick, Reuven, and Michael Hutchinson. 2001. "Banking and Currency Crisis: How Common are Twins?" In Financial Crises in Emerging Markets, eds. Reuven Glick, Ramon Moreno, and Mark M. Spiegel. Conference at the Center for Pacific Basin Monetary and Economic Studies at the Federal Reserve Bank of San Francisco, Sept. 23-24, 1999, Cambridge, UK: Cambridge University Press.

Henry, Peter Blair. 2000. "Stock market Liberalization, Economic Reform, and Emerging Market Equity Prices." Journal of Monetary Economics 55(2), pp. 529-564. 
Jeanne, Olivier. 2007. "International Reserves in Emerging Marketss Countries: Too Much of a Good Thing?" BPEA .

Jeanne, Olivier, and Romain Ranciere. 2006. "The Optimal Level of International Reserves for Emerging Market Countries: Formulas and Applications.” WP 06/229, IMF.

Kaminsky, Graciela L., and Carmen M. Reinhart. 1999. "The Twin Crises: The Cause of Banking and Balance-of-Payments Problems." The American Economic Review 89(3), pp. 473-500.

Kraay, Art. 1998. "In Search of Macroecconomic Effects of Capital Account Liberalization." World Bank, Development Research Group, Washington, DC.

Lane, Philip R., and Gian Maria Milesi-Ferretti. 2006. "The External Wealth of Nations Mark II: Revised and Extended Estimates of Foreign Assets and Liabilities, 1970-2004." Tech. rep., IMF.

Martell, Rodolfo, and Rene Stulz. 2003. "Equity-Market Liberalizations as Country IPO's." The American Economic Review 93(2), pp. 97-101.

Mendoza, Enrique G. 2002. "Credit, Prices, and Crashes: Business Cycles with a Sudden Stop." In Preventing Currency Crises in Emerging Markets, eds. Sebastian Edwards, and Jeffrey A. Frankel, chap. 7. NBER Conference Report, Chicago: University of Chicago Press, pp. 335-383.

Mendoza, Enrique G. 2006. "Endogenous Sudden Stops in a Business Cycle Model with Collateral Constraints: A Fisherian Deflation of Tobin's Q." Working Paper 12564, National Bureau of Economic Research, Cambridge, MA.

Mendoza, Enrique G. 2010. "Sudden Stops, Financial Crises and Leverage." The American Economic Review 100(5), pp. 1941-66.

Mendoza, Enrique G., Vincenzo Quadrini, and Jose-Victor Rios-Rull. 2009. "Financial Integration, Financial Development,and Global Imbalances." Journal of Political Economy 117(3).

Mendoza, Enrique G., and Katherine A. Smith. 2006. "Quantitative Implications of a Debt-Deflation Theory of Sudden Stops and Asset Prices." Journal of International Economics 70, pp. 82-114. 
Ostry, J., and C. Reinhart. 1992. "Private saving and terms of trade shocks: Evidence from developing countries." Imf staff papers. 


\section{Appendix}

Industrial countries:

Australia, Austria, Belgium, Canada, Denmark, Finland, France,Germany, Greece,Ireland, Italy, Japan, Netherlands, New Zealand, Norway, Portugal, Spain, Sweden, Switzerland, United Kingdom, and United States

Emerging Market Economies:

Algeria, Argentina, Brazil, Bulgaria, Chile, China, Colombia, Costa Rica, Côte d'Ivoire, Czech Republic, Ecuador, Egypt, Estonia, Hong Kong , Hungary, India, Indonesia, Israel, Saudi Arabia, Kuwait, Libya, Iran, Jordan, Korea, Latvia,Lithuania, Malaysia, Mexico, Morocco, Nigeria, Pakistan, Peru, Philippines, Poland, Romania, Russia, Singapore, Slovak Republic, Slovenia,South Africa, Thailand, Turkey, Uruguay, and Venezuela.

The data on countries external capital structure used in Figures 1 and 2 comes from Lane and Milesi-Ferretti (2006), updated through 2007. GDP weights are time varying. Net calculations refer to assets minus liabilities. Debt assets include portfolio debt, other debt, and reserves minus gold. Debt liabilities refer to portfolio debt and other debt. Equity assets and liabilities include portfolio equity and foreign direct investment.

The data for Figure A.1 on measures of financial integration comes from Chinn and Ito (2007), updated through 2009. These integration measures are averaged by country type using a simple average versus a weighted average. 
Figure A.1: Financial Integration Measures

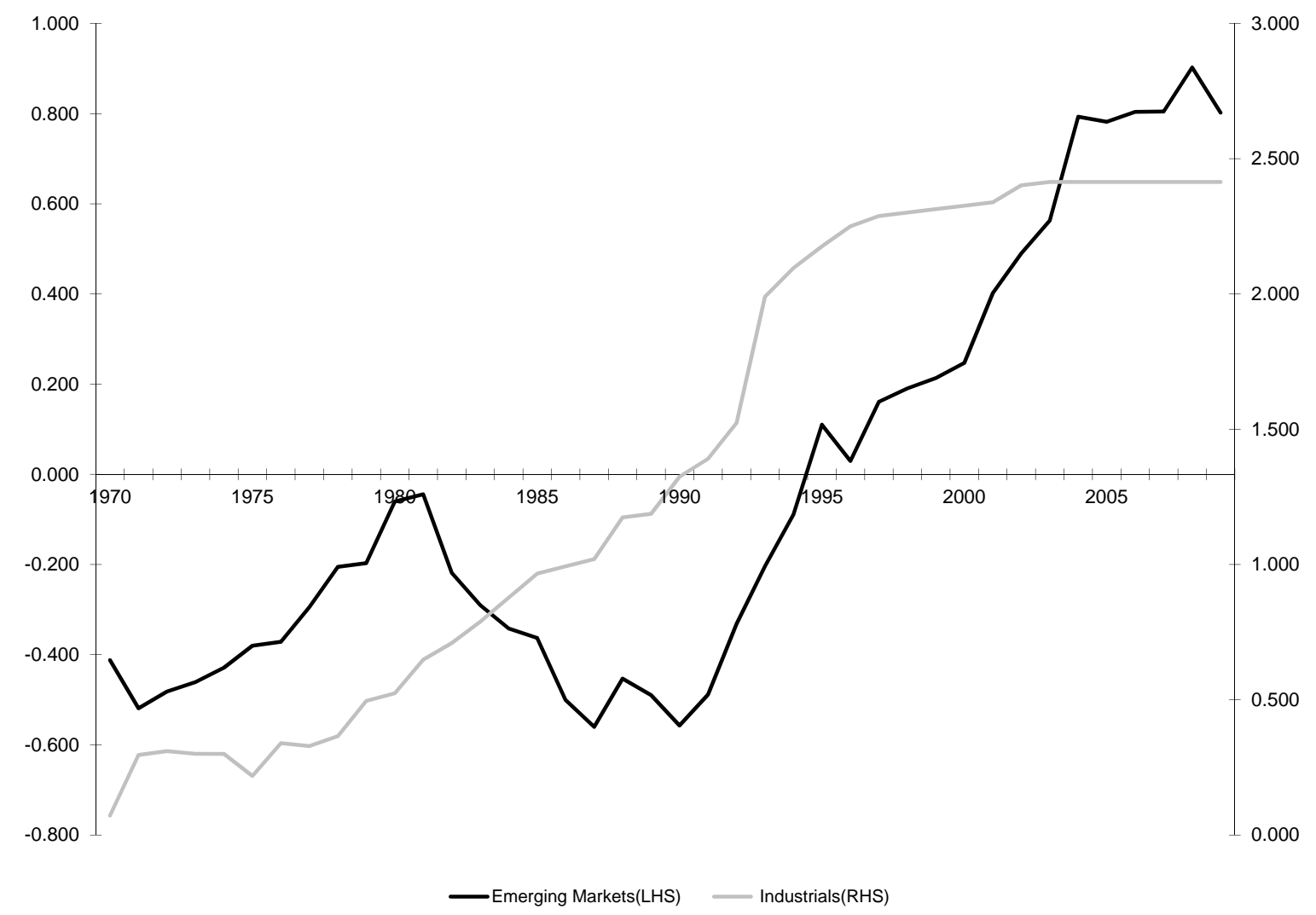

Note: Original source Chinn and Ito (2007) but since updated through 2009. See Appendix for a list of included countries. 